\title{
Is Central Bank Intervention Effective Under Inflation Targeting Regimes? The Case of Colombia
}

\author{
Herman Kamil
}





\title{
IMF Working Paper
}

\author{
Western Hemisphere Department
}

Is Central Bank Intervention Effective Under Inflation Targeting Regimes?

The Case of Colombia

\section{Prepared by Herman Kamil ${ }^{1}$}

Authorized for distribution by Benedict Clements

April 2008

\begin{abstract}
This Working Paper should not be reported as representing the views of the IMF. The views expressed in this Working Paper are those of the author(s) and do not necessarily represent those of the IMF or IMF policy. Working Papers describe research in progress by the author(s) and are published to elicit comments and to further debate.
\end{abstract}

Policymakers in many emerging markets are attempting to resist currency appreciation while simultaneously meeting targets for inflation. Using the recent experience of Colombia between 2004 and 2007, this paper examines the effectiveness of the Central Bank's intervention in stemming domestic currency appreciation under an inflation targeting regime. The results indicate that exchange rate intervention was effective during 2004-2006, when foreign currency purchases were undertaken during a period of monetary easing. During 2007, on the other hand, intervention was ineffective in reversing or slowing down domestic currency appreciation, as large-scale intervention became incompatible with meeting the inflation target in an overheating economy. Currency derivative markets - which have grown in depth and sophistication-played a key role in blunting the effectiveness of intervention.

JEL Classification Numbers: F31, F32, G13.

Keywords: central bank intervention; effectiveness; derivatives markets.

\footnotetext{
${ }^{1}$ The author would like to thank Kathryn Domínguez and Linda Tesar for their comments and guidance; also to Roberto Benelli, Andrew Berg, Jean-Francois Dauphin, María Gonzalez, Robert Rennhack, Jim Rowe, Jeromin Zettelmeyer and, in particular, Ben Clements for their useful feedback on previous drafts. This paper would not have been possible without the generous support of several colleagues at the Banco de la República de Colombia: Diana Mejía, Silvia Mera, Ximena Recio, Alejandro Reveiz, Luisa Silva, Carlos Varela, Hernando Vargas, and especially Jorge Toro. Genevieve Lindow provided excellent research assistance. All remaining errors and omissions are the author's own. The views expressed in this paper are those of the author and do not necessarily represent those of the International Monetary Fund.
} 


\section{Contents}

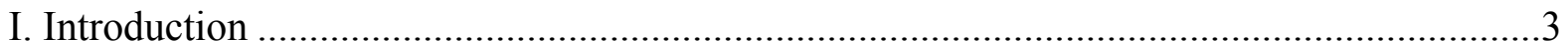

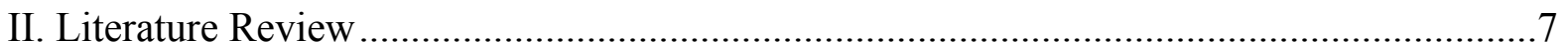

III. Intervention and Monetary Policies: A Tale of Two Periods .........................................

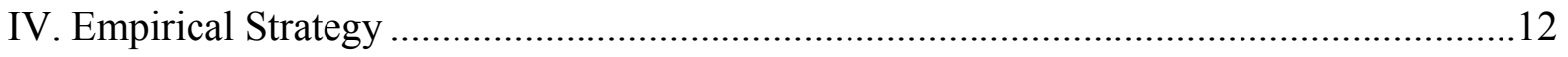

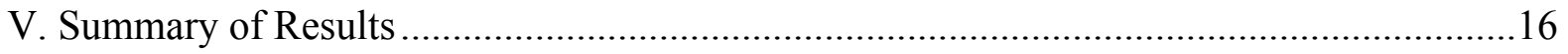

VI. Potential Policy Lessons ...........................................................................................24

A. Limits to Intervention Imposed by the Inflation Targeting Regime ......................24

B. The Role of Derivatives Markets in Blunting Central Bank Intervention ..............26

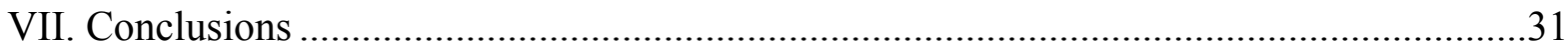

Figures

1. Central Bank of Colombia's Intervention Operations and Movements

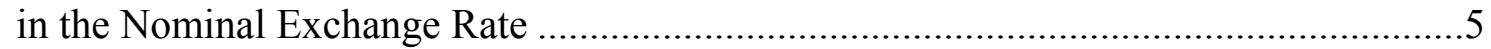

2. Central Bank of Colombia's Intervention and Movements in the Policy Lending Rate .....5

3. Output Gap in Colombia .......................................................................................21

4. Evolution of Inflation and Inflation Expectations vis-à-vis the Inflation Target..............21

5. Credibility of the Inflation Target...............................................................................25

6. Traded Value in On-Shore Currency Derivatives Market between Local Colombian Banks and Off-Shore Entities...................................................................26

7. Net Creditor Position of the Colombian Central Bank vis-à-vis the Financial Sector and Behavior of Interest Rates...................................................27

8. Derivative Markets Can Blunt Central Bank Intervention Operations

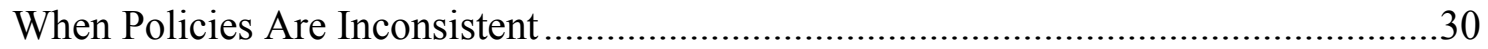

Tables

1. Summary Statistics on Daily Central Bank Intervention in Foreign Exchange Market....11

2. Determinants of Colombia Central Bank’s Daily Discretionary Intervention in FX Spot Market ............................................................................................ 17

3. Impact of Central Bank Intervention on Exchange Rate Level .....................................19

4. Effect of Central Bank Intervention on Volatility of Exchange Rate.............................23

5. Dynamic Effects of Central Bank Intervention .........................................................24

Appendixes

I. Summary Statistics on the Unconditional Distribution of Daily

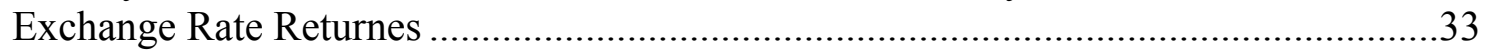

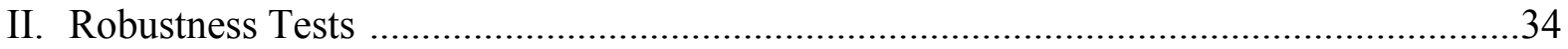

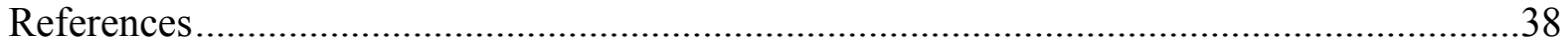




\section{INTRODUCTION}

In this paper, I assess the impact of sterilized intervention operations on the level of the nominal exchange rate in Colombia from September 2004 to April 2007. During most of this period, the Central Bank engaged in frequent - and at times sizable - discretionary purchases of foreign exchange, with the intended effect of depreciating the domestic currency. The paper focuses on two central questions: (1) How effective was Central Bank's intervention in stemming domestic currency appreciation in Colombia? (2) What constraints - if any - did the inflation-targeting regime pose on the Central Bank's ability to influence the currency?

Identifying the effectiveness of intervention, and the circumstances under which it can be a useful policy tool, are key questions for economic policy today. A decade after many emerging market countries battled currency crises, policymakers now face the challenge of adjusting to rapidly appreciating currencies. To protect the competitiveness of their tradable sectors, many central banks have tried to resist domestic currency appreciation by intervening strongly in currency markets, typically through the accumulation of international reserves. ${ }^{2}$ At the same time, many of these same countries have adopted inflation-targeting regimes to anchor inflation expectations, most often using short-term interest rates as their main operating target. Thus, limiting currency appreciation-while at the same time controlling inflation — poses a policy dilemma for many emerging market countries (see IMF, 2007a, 2007b).

While an extensive literature exists on foreign exchange intervention for advanced economies, much less is known about its effectiveness as an independent policy tool in emerging markets. A major hurdle for doing research in emerging market economies has been the lack of official, high frequency data on central bank intervention operations (because of valuation changes, the magnitude of intervention operations cannot be inferred simply from changes in reserves). Moreover, it is often not possible to know, a priori, whether the authorities accumulate international reserves with the intent of affecting the exchange rate or for other reasons, such as self-insuring against external financial shocks. ${ }^{3}$

In this study, I use a new data set that includes official statistics on daily foreign exchange intervention by the Central Bank of Colombia (Banco de la República,

\footnotetext{
${ }^{2}$ Widespread central bank intervention seems to reflect the predominant view among policymakers that intervention is a useful policy tool to influence real exchange rates (Neely, 2007). Indeed, according to a 2005 study of the Bank of International Settlements, 85 percent of those interviewed characterized their interventions as being effective most of the time (Mihaljek, 2005). In this light, it often appears to be an attractive tool to respond to surges in capital inflows (see IMF, 2007c).

${ }^{3}$ Jeanne and Rancière (2006) and Aizenman and Lee (2007) analyze competing interpretations for the large increases in the hoarding of international reserves by developing countries.
} 
henceforth BdR). ${ }^{4}$ A key advantage of the intervention data used in this study is that it accurately reflects discretionary purchases of dollars made with the explicit intention to depreciate the value of the domestic currency vis-à-vis the U.S. dollar. As constructed, this data set excludes changes in reserves for reasons other than-and not related toinfluencing the level of the exchange rate. ${ }^{5}$ This allows for clean identification of the impact of central bank intervention on the exchange rate.

Besides the availability of a novel dataset, Colombia offers an ideal case to study the effects of central bank intervention in foreign exchange rate markets and derive policy lessons, for at least three reasons. First, Colombia has faced strong exchange rate appreciation pressures. Between December 2006 and May 2007, for example, Colombia ranked as the country with the highest nominal domestic currency appreciation in the world - both vis-à-vis the U.S. dollar and in nominal effective terms. Second, the period under study is punctuated by frequent, and at times large, discretionary purchases of foreign exchange to resist domestic currency appreciation. Figure 1 shows the two distinct episodes of discretionary intervention in the foreign exchange rate market analyzed in this study: the first period, spanning from September 2004 to March 2006, and a more recent period from January 2007 to April 2007. ${ }^{6}$ During these periods of intervention, BdR activity took place on almost 70 percent of business days and the scale of official intervention was significant relative to the daily turnover in the market, reaching 50 percent on some days.

Colombia is also an interesting case study because the two periods of discretionary intervention considered here are associated with two very different stances of monetary policy. The first period was characterized by constant or falling interest rates and a loosening of monetary policy. The second discretionary intervention episode, in turn, was marked by a tightening of monetary policy and an increase in nominal interest rates to reduce inflationary pressures in an overheating economy (Figure 2). This provides an ideal setting to analyze the interplay between monetary policy and exchange rate policy decisions under inflation-targeting regimes. In particular, the Colombian case provides an opportunity to test the hypothesis that discretionary intervention to stem domestic currency appreciation is more effective when there is consistency between monetary and exchange rate policy goals.

\footnotetext{
${ }^{4}$ Data on official intervention was kindly provided by the Banco de la República, and is not disclosed to the public at a daily frequency. For this reason, the use of the daily data in this paper is subject to confidentiality agreements.

${ }^{5}$ These include valuation effects, capitalization of interest gains, portfolio adjustment operations, or other foreign exchange transactions not aimed at influencing the exchange (such as the trading of foreign exchange to meet the needs of the central government).

${ }^{6}$ From March 2006 until mid-January 2007, the Colombian government stopped discretionary purchases and only intervened in the foreign exchange market through rules-based, non-discretionary foreign currency auctions to smooth exchange rate volatility. A more detailed description is provided in Section III.
} 
Figure 1. Central Bank of Colombia's Intervention Operations and Movements in the Nominal Exchange Rate

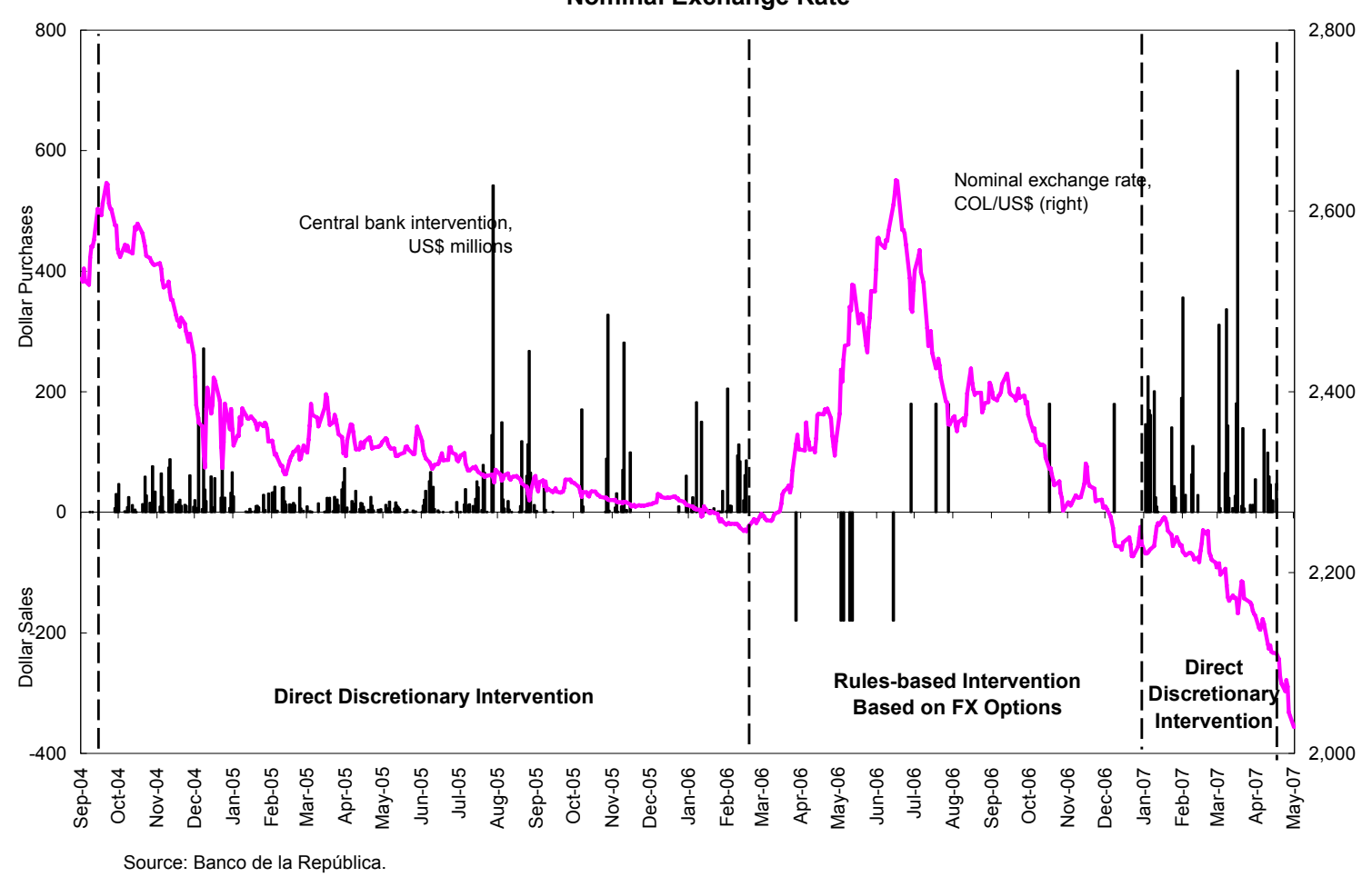

Figure 2. Central Bank of Colombia's Intervention and Movements in the Policy Lending Rate

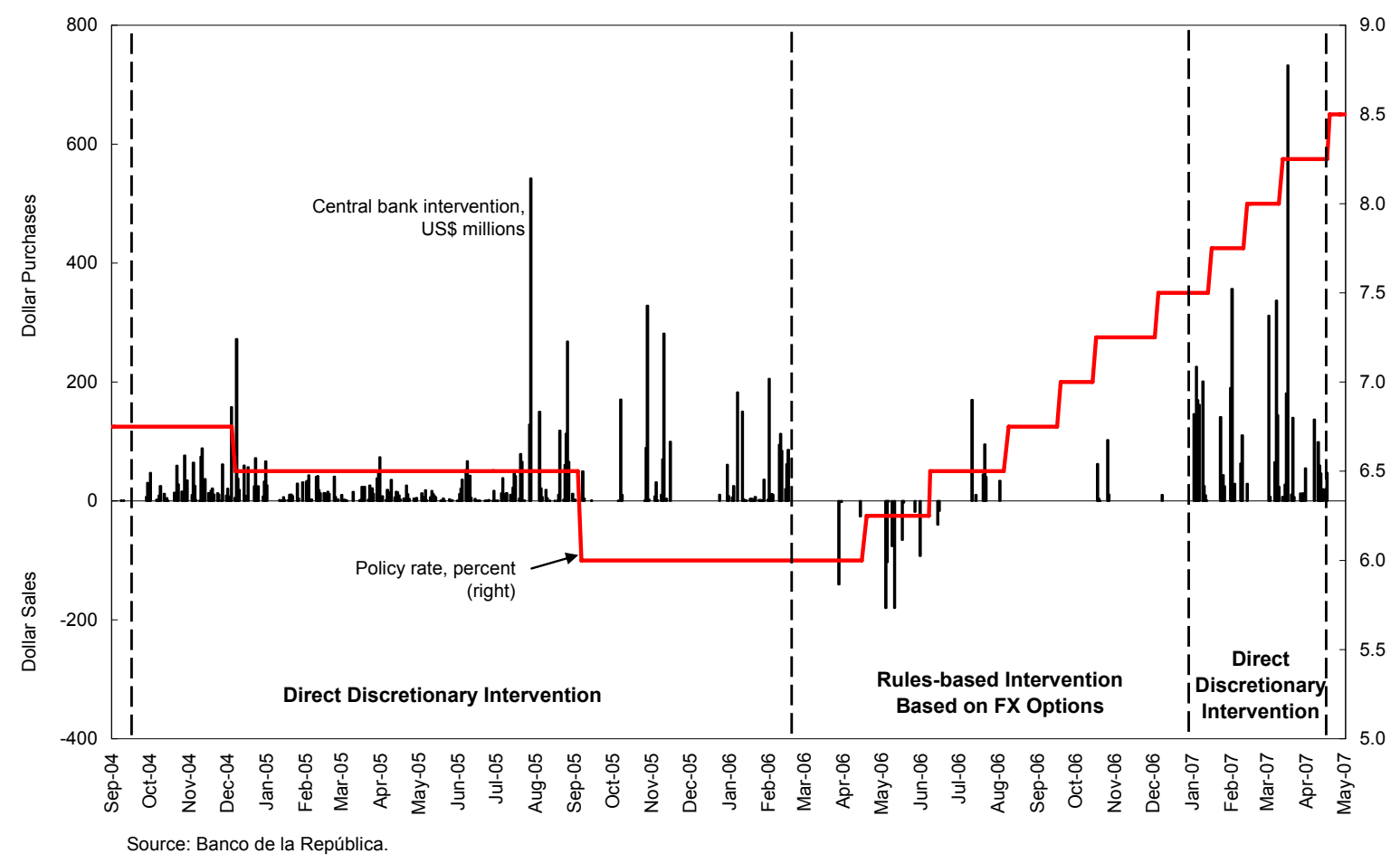


This paper's results suggest that the effects of BdR intervention varied sharply across the two periods. During the first period of discretionary intervention (September 2004March 2006), BdR foreign currency purchases had a statistically significant, positive impact on the exchange rate level, i.e., intervention led to a more depreciated exchange rate. However, while discretionary intervention was successful in moderating the appreciation trend, the effect of BdR's foreign currency purchases on daily exchange rate movements was economically small and short-lived. As such, substantial amounts of sterilized intervention were required to have a quantitatively important impact on exchange rate dynamics.

During the second period (January-April 2007), however, BdR intervention did not influence the level of the exchange rate, even in the short term. In practice, intervention operations aimed at depreciating the currency were dwarfed by offsetting increases in domestic interest rates and the market's reaction to higher-than-expected inflation announcements - both of which tended to appreciate the currency. Thus, during this period, sterilized intervention did not provide an independent channel for monetary policy.

The results suggest that coherence between intervention policy and inflation objectives was a critical factor in determining the success of discretionary intervention. During the first intervention episode, no contradiction existed between monetary and exchange rate policies. Purchases of international reserves were made in the context of decreasing policy rates and an economy operating below potential capacity. Because macroeconomic objectives were well aligned, foreign currency purchases credibly signaled an easing of monetary policy and the BdR was able to stem appreciation pressures without undermining its ability to meet the inflation target.

During the second period, however, tension existed between monetary and exchange rate policy goals. The BdR was torn between a concern for price stability in an overheating economy, on the one hand, and concern over the rapid pace of appreciation of the exchange rate, on the other. The BdR sought simultaneously to maintain price stability by raising interest rates, and preserve competitiveness by resisting currency appreciation. Rising interest rate had the consequence of attracting more capital inflows, thereby exacerbating appreciation pressures. At the same time, resisting currency appreciation (which typically feeds into lower domestic prices of imported goods) worked at crosspurposes with the goal of containing inflation.

In this environment, markets perceived the BdR as pursuing two mutually inconsistentand ultimately unsustainable - goals. Using estimates on the domestic currency's response to unexpectedly high inflation announcements, I show that markets expected monetary policy to remain firmly committed to the goal of reducing inflation-even if that meant increasing interest rates and, thereby, undoing intervention efforts. Foreign investors, realizing that the central bank would eventually focus on taming inflation (and 
eventually let the exchange rate appreciate), took unprecedented amounts of leveraged bets against the central bank (and the dollar) in the derivatives market - thereby limiting the effectiveness of intervention. Paradoxically, then, the BdR's perceived strong commitment to inflation actually undermined its ability to influence the exchange rate.

These results have important implications for policy design. The Colombian case suggests that successful intervention to stem domestic currency appreciation may be particularly difficult for an inflation targeter at advanced stages of the business cycle. The commitment to an inflation target limits the scope for lowering interest rates, and low upward exchange rate flexibility provides incentives for carry trade and leveraged bets on the currency through derivatives markets. Thus, while a government committed to reducing the value of its currency has, in theory, a large supply of "ammunition" (i.e., printing money to buy reserves), the inflation objective can in practice become a binding constraint that puts a limit to the amount of foreign reserves that a central bank can accumulate. $^{7}$

More generally, Colombia's experience provides useful policy lessons for other emerging markets facing the challenge of resisting domestic currency appreciation while at the same time controlling inflation. The analysis yields three key results. First, intervention can only be successful when there is no conflict between exchange rate and inflation objectives. In particular, central bank intervention to resist currency appreciation is likely to be effective when the economy is operating below full capacity and thus monetary easing is consistent with meeting the inflation target. ${ }^{8}$ Second, the inflation-targeting regime imposes limits to the sterilization of reserve accumulation when monetary policy needs tightening. Third, when one-sided, protracted discretionary intervention is perceived as unsustainable, inflation targeting regimes may be vulnerable to speculative attacks against the central bank-but attacks that appreciate the currency.

\section{LiteratURE REVIEW}

A large body of economic literature explores the efficacy of sterilized intervention in developed economies. ${ }^{9}$ The evidence suggests that sterilized intervention by industrialized countries has, at times, effectively influenced the value of currencies. ${ }^{10}$

\footnotetext{
${ }^{7}$ On the other hand, in the case of a defense of the value of the domestic currency, the cumulative amount of intervention is constrained by the stock of available reserves.

${ }^{8}$ See Holub (2004) for a very similar policy implication based on the experience of the Czech Republic with central bank intervention.

${ }^{9}$ Edison (1993) surveys the literature on central bank intervention from the 1980s through early 1990s; Sarno and Taylor (2001) provide a more recent survey of theory and empirical evidence.

${ }^{10}$ Dominguez and Frankel (1993) and Dominguez (2003) provide empirical evidence in this regard. For Japan, Ito (2002) found that large and infrequent intervention had quantitatively small but statistically significant effects on the dollar-yen nominal exchange rate.
} 
However, these effects are typically small in economic terms. Collectively, the recent literature for advanced economies has shown that intervention systematically moves the spot exchange rate only if the intervention is announced publicly, coordinated across countries, and is consistent with the underlying stance of fiscal and monetary policy. Additionally, a number of papers have examined the influence of intervention operations on daily exchange rate volatility and generally find evidence that intervention increases volatility: that is, for the major currencies, evidence is weak that sterilized intervention dampens volatility. ${ }^{11}$

However, literature on the effectiveness of intervention in emerging market economies is still sparse, in large part, because governments are reluctant to provide official data on their operations. ${ }^{12}$ The few papers that analyze central bank intervention at daily frequencies using official data find mixed results on its effectiveness. ${ }^{13}$ Domac and Mendoza (2002) conclude, in the context of Mexico and Turkey in the period 2001-02, that central bank foreign exchange sales (but not purchases) had a statistically significant influence on the exchange rate in both countries. In contrast, Tapia and Tokman (2004) found that actual intervention appeared to have a generally insignificant effect on contemporaneous exchange rate movements. Guimarães and Karacadag (2004) find that in Mexico foreign exchange sales had a small impact on the exchange rate level, but official intervention does not appear to systematically affect exchange rate levels in Turkey. ${ }^{14}$ With respect to the impact of intervention on exchange rate volatility, Domac and Mendoza (2002) find that intervention reduced exchange rate volatility in both countries. An opposite result was found in Guimarães and Karacadag (2004), who find that intervention tends to increase exchange rate volatility. ${ }^{15}$

\footnotetext{
${ }^{11}$ Dominguez (2006) and Cashin, Edison and Liang (2006) found that intervention increases exchange rate volatility, in contrast with claims by central banks that intervention does not increase (or is not associated with an increase in) volatility (Neely, 2007).

${ }^{12}$ Canales-Kriljenko (2003) argues that foreign exchange intervention may be more effective in developing and transition economies than in industrialized countries. Given the lower degree of international substitutability of emerging market assets, and the large size of interventions relative to currency market turnover in these countries, foreign exchange intervention could — in principle - have a sizeable effect on exchange rates.

${ }^{13}$ Disyatat and Galati (2007) provide a review of the existing literature on the effectiveness of intervention in emerging market countries. BIS (2005) contains descriptive case studies for a large number of emerging economies.

${ }^{14}$ Guimaraes and Karacadag (2004) use a different sample period for Mexico (1996 to 2003) and Turkey (2001 to 2003). For the case of Turkey, see also Ozge, Olcay, Ozlale and Sahinbeyoglu (2005).

${ }^{15}$ Recent cross-country empirical evidence, using monthly changes in gross reserves as a proxy for intervention operations, suggests intervention is unlikely to be effective in dealing with capital flows. Using a sample of emerging markets and small advanced countries, IMF (2007a) finds that resisting nominal exchange rate appreciation through sterilized intervention is likely to be ineffective when capital flows are persistent. Looking at the experience of five managed-float countries (India, Indonesia, Korea, the Philippines, and Thailand) over the period 2000-2007, IMF (2007b) finds limited evidence of systematic
} 
Empirical evidence for Mexico, Turkey and Chile, however, cannot be easily generalized to other emerging markets. First, given policy objectives, the finding that intervention has no impact on the spot exchange rate must be interpreted with caution. For example, the bulk of intervention undertaken in Mexico was aimed at accumulating reserves, rather than influencing the level of the exchange rate. Moreover, the mechanisms used in Mexico and Turkey for intervention (auctioning put and call foreign exchange options and pre-announced foreign exchange sale auctions, respectively), are very different from the ways developing countries today intervene (usually in the spot market on a discretionary basis). Finally, in Chile, the intervention strategy mostly relied on public announcements of potential (i.e., oral), as opposed to actual, interventions.

The papers closest to this study are by Gersl and Holub (2006) and Disyatat and Galati (2007), which both analyze the role of direct foreign exchange interventions in the Czech Republic since 1998. Gersl and Holub also discuss the consistency of the interventions with the inflation-targeting framework. Disyatat and Galati (2007) find no or only a very small (cumulative) impact of intervention on the spot exchange rate. Gersl and Holub (2006) also find some evidence that the intervention had a statistically significant, but short-lived and economically-unimportant, impact on the koruna's exchange rate. ${ }^{16}$

\section{Intervention and Monetary Policies: A Tale of Two Periods}

The BdR adopted an inflation-targeting scheme with a floating exchange rate in October 1999 , using the overnight repo interest rate as the main instrument of monetary policy. ${ }^{17}$ Despite adopting a flexible exchange rate regime, the BdR did not commit to totally forsake intervention in the foreign exchange market; rather, the BdR explicitly reserved the right to intervene to build-up the level of international reserves or to prevent excessive volatility in the foreign exchange market. Unlike most other central banks, BdR followed a rules-based intervention mechanism based on auctioning foreign currency

\footnotetext{
links between exchange rates and intervention. The authors also find mild evidence that intervention may be associated with lower exchange rate volatility.

${ }^{16}$ Ho and McCauley (2003) provide an earlier analysis of the use of intervention in the context of money or inflation targets, while Mohanty and Turner (2006) discuss the possible distortions in the domestic financial caused by sustained sterilization efforts of central bank intervention. Edwards (2006) and Chang (2007) provide a discussion on whether the exchange rate should play a role in determining the monetary policy stance under inflation targeting in emerging markets, and analyze the rationale for reserve accumulation and foreign exchange intervention in these countries. More recently, Lavigne (2008) discusses the recent trends in sterilized intervention among emerging market economies, the fiscal costs associated to them and the recent increase in alternative sterilization methods, such as the rise in reserve requirement ratios.

${ }^{17}$ This reform replaced a system of pre-announced exchange rate bands that had been in place since 1994 and was subject to speculative attacks during 1998-99. See Vargas (2005) for a detailed account of monetary policy since 1999 .
} 
options. The rules, timing, and magnitude of these interventions were largely predetermined and known by market participants. ${ }^{18}$

On September 17, 2004, facing an escalating appreciation of the peso, the BdR announced its decision to introduce direct and discretionary foreign exchange intervention operations in the spot market. The announcement indicated that the BdR would buy up to US\$1,000 million in international reserves until the end of the year. By supplementing its rules-based intervention strategy with the possibility of doing it discretionally, the Central Bank board was clearly stating its purpose to diminish the peso's appreciation, which had reached 13.3 percent in real terms between April 2003 and September 2004. ${ }^{19}$ By December 22, 2004 the BdR upended its discretionary intervention strategy, announcing that direct foreign currency purchases would continue indefinitely, with no fixed amount or duration. Almost simultaneously, the BdR gave a clear signal to the market of a loosening in its monetary policy stance, by reducing its interest rates by 25 bps and closing its contraction REPO facilities.

Table 1 provides descriptive information on BdR's discretionary intervention operations. ${ }^{20}$ Between September 202004 and March 2 2006 - the first period of discretionary intervention-Colombian authorities intervened in the peso-dollar exchange rate market on 251 days, or approximately 70 percent of the total trading days. The average size of daily foreign currency purchases was almost US\$30 million, approximately 5 percent of total market turnover. The amounts purchased varied considerably, however, with the largest intervention exceeding 40 percent of daily volume traded in the market. During this period, the BdR carried out intervention on several successive business days, with the longest intervention spell reaching 36 days.

\footnotetext{
${ }^{18}$ A detailed description of the operational aspects can be found in Uribe and Toro (2004). Mandeng (2003) and Ramirez (2004) analyze the experience of options-based foreign exchange intervention in Colombia before 2004. The authors find that these have only been moderately successful in reducing exchange rate volatility.

${ }^{19}$ A policy response to the appreciation was also deemed necessary because the appreciation was expected to reduce inflation significantly below the 2004 inflation target of 5.5 percent.

${ }^{20}$ Historical data on official intervention is not available to the public at a daily frequency, and the BdR only publishes the aggregate monthly amount of its net purchases of dollars, ten days after the end of each month.
} 
Table 1. Summary Statistics on Daily Central Bank Intervention in the Foreign Exchange Market

\begin{tabular}{lcc}
\hline & \multicolumn{2}{c}{ Regimes of Un-Announced Discretionary Intervention } \\
\cline { 2 - 3 } & $\begin{array}{c}\text { Fecond Period } \\
\text { Jan 2007-Apr 2007 }\end{array}$ \\
\hline Frequency & 357 & 73 \\
Number of trading days & 251 & 44 \\
Number of intervention days & 70.3 & 60.3 \\
Frequency of central bank intervention (in percent) 1/ & & 103 \\
Intensity & 29 & 733 \\
Average value of intervention (in US\$ millions) 2/ & 542 & 10.7 \\
Maximum daily intervention (in US\$ millions) & 5.1 & 48.6 \\
Average relative value of intervention (in \% of mkt. turnover) 2/ & 40.9 & 9 \\
Maximum relative value of intervention (in percent) & & 9 \\
Duration & 36 & 9 \\
Longest intervention spell (in business days) 3/ & & \\
\hline
\end{tabular}

Sources: Author's calculations based on data provided by the Banco de la República.

Note: Purchases are in millions of U.S. dollars. The first period goes from September 20, 2004 to March 1, 2006. The second period starts on January 15, 2007 and ends on April 30, 2007.

$1 /$ Number of days in which central bank intervened, as a fraction of total trading days.

2/ Average magnitudes calculated over days on which intervention occurred.

3/ The longest continuous stretch of central bank intervention within each sub-period.

The BdR stopped its discretionary interventions at the beginning of March 2006, when uncertainty about the US Federal Reserve policy led to a reversal of capital inflows and a sudden moderation of appreciation pressures. Starting in March 2006, the Colombian government only intervened in the foreign exchange market by buying and selling foreign exchange options to smooth exchange rate volatility. ${ }^{21}$

Beginning in July 2006, however, the exchange rate resumed its path of sustained appreciation, accumulating an appreciation of 15 percent by the end of 2006. On January 15,2007 , after a pause of nine months, the BdR re-initiated discretionary interventions to counteract the mounting appreciation pressures. ${ }^{22}$ During the second

${ }^{21}$ Under this mechanism, the Central Bank auctions call (put) options to sell (buy) foreign exchange for up to 180 million when the peso depreciates (appreciates) by more than 2 percent from its 20 -day moving average. They expire one month after the auction date and can only be exercised when the official exchange rate is above (US\$ call) or below (US\$ put) its 20-day moving average. During this period, the volatility rule was triggered 11 times and led to a net reduction of reserves of US\$360 million.

${ }^{22}$ Almost two weeks later, in its official Communiqué dated January 26, the BdR made public its determination to carry out 'massive' foreign exchange rate intervention, aimed at preventing what the central bank perceived as temporary appreciation pressures derived from the conversion of large privatization revenues to the domestic currency. 
intervention episode (from January 15, 2007 to April 30, 2007), the frequency of BdR activity in the market was lower (60 percent of business days), but the amount of intervention was on average larger - especially when compared to the total activity in the foreign exchange rate market (see Table 1 above). During the first four months of 2007 , the BdR accumulated US $\$ 4.5$ billion by actively intervening in the market. ${ }^{23}$

In contrast with the first discretionary intervention episode, BdR's dollar purchases during 2007 occurred against a backdrop of tightening monetary policy. Since April 2006 the BdR Board had started to raise interest rates progressively in a bid to slow bank lending and curb inflationary pressures. By January 2007 it had accumulated increases amounting to 175 basis points, and continued to raise interest rates throughout the period of discretionary intervention. These rate increases led to a considerable upward shift in interest rate differentials with the U.S., which widened from 125 bps at the end of April 2006 to 325 bps at the end of April 2007.

During the period under study, official discretionary intervention operations were conducted exclusively in the spot market, and the BdR did not intervene in the foreign exchange forward market nor did it conduct off-market foreign exchange operations. ${ }^{24}$ Interventions were automatically sterilized to achieve the desired level of the operating target of monetary policy, the short-term interest rate. Daily intervention operations were not publicly announced, nor did the BdR officially confirm or deny reports in the financial press or wire services regarding its presence in the foreign exchange market. Moreover, the BdR did not make explicit the rules for discretionary intervention, and there was no pre-announced target level for the exchange rate.

\section{EMPIRICAL STRATEGY}

Assessing the effectiveness of intervention is complicated by two empirical challenges. First, it is not possible to observe the counterfactual-i.e., what the exchange rate movement would have been if intervention had not occurred, in days when the authorities did in fact intervene. ${ }^{25}$ Second, disentangling the causal effect of intervention on

\footnotetext{
${ }^{23}$ Over the whole sample period, the BdR accumulated approximately US\$ 11 billion through discretionary intervention operations, almost doubling the amount outstanding in September 2004. As a share of shortterm debt, reserves rose from 92 percent in September 2004 to 172 percent in April 2007.

${ }^{24}$ Central banks in several developing countries (Croatia, Czech Republic, Mexico and South Africa, among others) have at times engaged in "passive intervention", i.e., outright transactions conducted offmarket aimed at insulating the foreign exchange market from large external receipts (such as oil revenue sales by state owned enterprises, proceeds from privatization revenues, foreign aid or surrender requirements). Moreno (2005) notes that in Mexico, for example, the Mexican oil company Pemex can only acquire pesos by depositing its dollars at the central bank.

${ }^{25}$ In other words, simultaneous observation of foreign exchange purchases and domestic currency appreciation cannot be interpreted as evidence that intervention was ineffective. For instance, in the absence of intervention, the exchange rate might have followed a more appreciated path. The lack of a counterfactual is typical of policy evaluation, as described in the literature of treatment effects (see
} 
exchange rates is further complicated by the fact that the decision (and extent) of intervention may be endogenous to past exchange rate movements. That is, a central bank is more likely to buy foreign currency when the domestic currency has been strengthening. Failing to account for the two-way causality between exchange rate changes and intervention is likely to bias the analysis toward finding that the latter has no impact on exchange rates.

To overcome this identification problem, I use a two-stage instrumental variable model based on estimates of the BdR's reaction function. ${ }^{26}$ For each period of discretionary intervention, I estimate a foreign exchange intervention function for the amount of intervention. I then use the predicted values from the first stage as an instrument for actual interventions in a reduced-form model of exchange rate returns. The model allows for GARCH effects in the conditional variance. ${ }^{27}$

In the first-stage, foreign exchange intervention policy is described as a dynamic censored regression (Tobit) model of the following form:

$I N T_{t}=\max \left(0, \gamma_{0}+\gamma_{1} I N T_{t-1}+\gamma_{2}\left(\Delta \ln s_{t-1}\right)+\gamma_{3}\left(\ln s_{t-1}-\ln s_{t-1}^{T}\right)+\gamma_{4} N e w \operatorname{Inf} f_{t-1}\right)+\varepsilon_{t}$

where INT denotes the actual amount of dollar purchases, $s_{t}$ is the nominal exchange rate (expressed in terms of local currency per U.S. dollar), and $s^{T}$ is a backward-looking, 20-day moving-average component, a proxy for the (time-dependent) 'target' nominal exchange rate:

$$
s_{t}^{T}=\frac{1}{20} \sum_{j=1}^{20} s_{t-j}
$$

The specification in (1)-(2) allows interventions to be motivated by two exchange rate factors: a very short-term one (the daily percentage change in the exchange rate, $\Delta \ln s_{t-1}$ ),

Imbens, 2004, for a recent survey). However, in the case of the exchange rate intervention literature, the problem is compounded by the lack of a consensus model on exchange rate determination to estimate the counterfactual.

${ }^{26}$ The same methodology is used in Guimarães and Karacadag (2004) and Disyatat and Galati (2007). For recent reviews of the empirical literature on the impact of foreign exchange interventions on the level and variance of exchange rates, see Hutchinson (2003) and Neely (2005).

${ }^{27}$ Other authors (most notably, Fatum and Hutchison, 2003) have used an event-study approach to analyze the effectiveness of intervention. This methodology, however, is well suited when interventions take place only sporadically — which is not the case in Colombia, as described above. 
and by the percentage deviation of the exchange rate from 'target'. ${ }^{28}$ This enables to test if the BdR systematically "leaned against the wind" and/or attempted to counter short-term exchange rate trends. In addition, the model controls for the possibility that official announcements of inflation data can influence the decision to intervene. NewsInf is the "news" contained in the announcement - the difference between the actual announced level of monthly inflation and the market's expectation of that announcement. ${ }^{29}$ Finally, because interventions usually come in clusters, we include the lagged dependent variable as a regressor to account for persistence effects. ${ }^{30}$

In the second stage, we estimate a $\operatorname{GARCH}(1,1)$ model of the peso-dollar exchange rate return with the following general specification: ${ }^{31}$

$$
\begin{aligned}
& \Delta\left(\ln s_{t}\right)=\mu+\beta_{0} \Delta\left(\ln s_{t-1}\right)+\beta_{1} \overline{I N} \bar{T}_{t}+\beta_{2}\left(i-r^{*}\right)_{t}+\beta_{3} \Delta(\text { EMBI spread })_{t}+\beta_{4} \text { NewsInf }_{t-1}+ \\
& \beta_{5} \text { AutomINT }_{t}+\varepsilon_{t} \\
& \varepsilon_{t} \mid \Omega_{t-1} \sim \mathrm{N}\left(0, \sigma_{t}^{2}\right) \\
& \sigma_{t}^{2}=\alpha_{0}+\alpha_{1} \sigma_{t-1}^{2}+\alpha_{2} \varepsilon_{t-1}^{2}+\alpha_{3} I N T_{t}+\alpha_{4}\left(i-r^{*}\right)_{t}+\alpha_{5} \Delta(\text { EMBI spread })_{t}+\alpha_{6} \mid \text { NewsInf } f_{t-1} \mid+ \\
& \alpha_{7} \text { AutomINT }_{t}+\sum_{i=1}^{4} \delta_{i} D_{i t}+\delta_{5} \text { Post }_{t}+v_{t}
\end{aligned}
$$

where: $\Delta(\ln s)$ is the daily percentage change in the nominal exchange rate (such that a positive change is a depreciation of the Colombian peso); $\overline{I N} \bar{T}$ is the instrumented level of BdR intervention in the foreign exchange market, as explained above; $\left(i-r^{*}\right)$ is the

\footnotetext{
${ }^{28}$ The order of the moving average representation has varied across studies. In the case of Colombia, I set it to a 20-day moving average, which is the trigger used in operations with options under the rules-based intervention scheme.

${ }^{29}$ Market expectation is measured as the median forecast of the monthly inflation value culled from opinion surveys conducted by Bloomberg News Service. The surveys are taken very close to the time of the announcement, and ask about expectations of the change in domestic CPI over the previous month.

${ }^{30}$ Edison (1993) and Almekinders (1995) survey empirical work on the determinants of intervention.

${ }^{31}$ The nominal exchange rate data is provided by the $\mathrm{BdR}$ and corresponds to the value-weighted average of all foreign exchange rate transactions in the spot market throughout the day (officially known as TRM, or Tasa Representativa de Mercado). The daily returns for the peso/dollar exchange is calculated as the difference in the logarithm of the exchange rate of two consecutive business days. Table A1 in Appendix I reports various descriptive statistics on the unconditional distribution of exchange rate returns. All the series appear to have non-normal distributions, with significant linear and non-linear serial correlations, especially during the first period. Thus, I follow Baillie and Bollerslev (1989) and Dominguez (1998) and use a univariate Generalized Autoregressive Conditional Heteroskedasticity (GARCH) model for the analysis.
} 
interest rate differential between the domestic interbank rate and the US Fed's fund rate, in percent per year; EMBI spread is the yield spread on a sovereign foreign currency bond over a comparable U.S. treasury bond in percent per year; ${ }^{32}$ AutomINT is a dummy variable denoting the days in which the automatic intervention rule through options was triggered; ${ }^{33} D_{i t}$ are day-of-the-week dummy variables (for example, $D_{1 t}=1$ for Mondays, where Friday is the omitted category); Post $_{t}$ is a holiday dummy variable that is equal to one on the day following the market being closed for any reason other than a weekend; | denotes the absolute number operator and $\varepsilon_{t}$ is the unexpected return which is used to model the conditional volatility of the exchange rate in the volatility equation (5).

Finally, $\sigma_{t}^{2}$ is the conditional variance and allows for the possibility of time-varying and clustering conditional volatility. The conditional distribution of the disturbance term is normal with variance $\sigma^{2}$.

Several features of the specification are worth noting. Equation (3) of the empirical model (the "mean" equation) analyzes changes in the exchange rate return (depreciation or appreciation against the dollar) as a function of intervention, controlling for other factors affecting exchange rates at a daily frequency. ${ }^{34}$ The main focus is on the estimate of $\beta_{1}$, the contemporaneous impact of intervention on the level of the exchange rate. If central bank intervention is effective, then purchases of foreign currency $(I N T>0)$ will depreciate the domestic currency $(\Delta(\ln s)>0)$ and so $\beta_{1}$, the parameter of interest, will be positive and statistically significant.

The estimation controls for financial developments affecting short term exchange rate movements. The interest differential aims to capture the possible impact of monetary policy actions and local money market conditions on the exchange rate. This is especially important during the first period, when the Central Bank was easing monetary policy. ${ }^{35}$ Yield spreads on sovereign external debt are included as a measure of country risk and foreign investor sentiment, which are potential key determinants of demand for local

\footnotetext{
${ }^{32}$ This is measured in first differences to achieve stationarity.

${ }^{33}$ During the discretionary intervention episodes, the intervention rule was triggered twice: on December 20, 2004 and on March 30, 2007. The empirical model above accounts for the impact of these automatic interventions in assessing the effects of discretionary intervention.

${ }^{34}$ Given the reduced-form nature of the estimation, the framework can only identify the average response of exchange rate returns to intervention operations. It does not, however, identify a structural relationship or the channels through which intervention may affect exchange rates.

${ }^{35}$ The distinction between unsterilized and sterilized intervention is important: changes in the monetary supply would naturally affect the exchange rate, so it would not be surprising to find that unsterilized intervention is effective in depreciating the currency.
} 
currency. I also account for the possible influence of surprises in inflation announcements, that may arrive on the same day on which intervention is carried out.

\section{SumMary OF Results}

\section{Central bank reaction function}

Table 2 reports the results on the determinants of foreign exchange intervention activity. Results for the first period of intervention are consistent with the hypothesis that the BdR attempted to "lean against the wind," i.e., to smooth the speed of adjustment of the exchange rate and thus avoid large appreciations on a given day. The coefficient for the reaction on the short-term change in the spot exchange rate has the right sign and is statistically significant, suggesting that between 2004 and 2006, the BdR reacted systematically to previous-day exchange rate changes in deciding the amount to intervene. The estimate of $\gamma_{2}$ implies that, on average, a 1 percent appreciation of the exchange rate was met by a central bank purchase of US\$14 million the following day (see Table 2). At the same time, results shown in the first column of Table 2 suggest that another motivation for BdR's intervention was to slow or reverse the trend of appreciation during this period. The point estimates imply that in response to a 1 percent deviation of the exchange rate below target, the BdR was inclined to purchase on average US\$13 million during the first period. ${ }^{36}$

The results for the second period of intervention, however, suggest that Colombian authorities did not appear to intervene in response to an acceleration of peso appreciation, that is, to smooth out exchange rate fluctuations. Indeed, the value for $\gamma_{2}$ in the second column of Table 2 has the expected sign but is estimated very imprecisely. Rather, results indicate that a key motivation for discretionary interventions during the second period was a desire to correct the deviation of the exchange rate from its (moving) target value. The point estimate for $\gamma_{3}$ implies that in response to a 1 percent negative deviation of the exchange rate with respect to target, the BdR would purchase on average US\$54 million during 2007 to slow appreciation. These intervention efforts to guide the exchange rate toward a target value were more pronounced than during the first period of intervention.

\footnotetext{
${ }^{36}$ Since the motivation for BdR intervention was not announced, the policy criteria of 'leaning against the wind' and 'reverse the trend of appreciation' are only indicative of actual policy intentions. However, the negative estimated coefficients on $\gamma_{2}$ and $\gamma_{3}$ conforms to our priors and those of market participants, as well as unofficial BdR statements.
} 
Table 2. Determinants of Colombia Central Bank's Daily Discretionary Intervention in FX Spot Market

\begin{tabular}{|c|c|c|}
\hline & $\begin{array}{r}\text { First Period } \\
\text { September 2004-March } 2006\end{array}$ & $\begin{array}{r}\text { Second Period } \\
\text { January 2007-April } 2007\end{array}$ \\
\hline$\gamma_{1}($ Lagged Dependent Variable) & $\begin{array}{r}0.16 \\
(0.13)\end{array}$ & $\begin{array}{l}0.40 * * \\
(0.19)\end{array}$ \\
\hline \multicolumn{3}{|l|}{ Exchange Rate Acceleration } \\
\hline$\gamma_{2}$ (Exchange Rate change, in precentage) (t-1) & $\begin{array}{c}-14.10 * * \\
(5.5)\end{array}$ & $\begin{array}{r}-67.80 \\
(55.85)\end{array}$ \\
\hline \multicolumn{3}{|l|}{ Deviation of Exchange Rate Level } \\
\hline$\gamma_{3}($ Percentage Deviation from Target $)(\mathrm{t}-1)$ & $\begin{array}{l}-13.40 * * * \\
(4.13)\end{array}$ & $\begin{array}{l}-54.78 * * \\
(26.3)\end{array}$ \\
\hline \multicolumn{3}{|l|}{ Unexpected Component of Inflation Announcement } \\
\hline$\gamma_{4}$ (Actual minus Expected Value of Inflation) (t-1) & $\begin{array}{l}-90.340 * * \\
(40.1)\end{array}$ & $\begin{array}{r}52.15 \\
(55.16)\end{array}$ \\
\hline \multicolumn{3}{|c|}{ Diagnostics } \\
\hline Cragg \& Uhler's R2 & 0.10 & 0.19 \\
\hline Prob $>$ LR & 0.00 & 0.00 \\
\hline Included observations & 356 & 73 \\
\hline Censored Observations (in percent) & 29.7 & 39.6 \\
\hline
\end{tabular}

Source: Author's calculations.

Note: This table reports estimation of a Tobit model for equation (1) in the text. The dependent variable is the amount of dollars purchased by the Central Bank (in millions) in the domestic foreign exchange market to influence the value of the home currency. Estimated coefficients are the marginal effects of a unit change in the explanatory variables, evaluated at sample means. Robust standard errors are reported in parentheses. The model includes a constant, not shown. Asterisks denote significance of coefficients, with ${ }^{* * *},{ }^{* *}$ and ${ }^{*}$ indicating significance at the $1 \%, 5 \%$ and $10 \%$ level, respectively.

During the second period, foreign exchange interventions became more highly correlated over time. In particular, the results suggest that once intervention was carried out one day, another intervention of a similar magnitude (and in the same direction) was likely to take place the following day. ${ }^{37}$ This observation provides important insights into the muted impact of the BdR's activity in the foreign exchange: as intervention became more predictable, its ability to surprise the market diminished. In effect, market participants may have been better able to anticipate the BdR's operations, especially considering the

\footnotetext{
${ }^{37}$ Dynamic considerations did not play an important role in determining the intervention strategy used by the BdR in the first period.
} 
high frequency of intervention and that all interventions were carried out in the same direction. $^{38}$

\section{Effects on exchange rates}

The estimates in Table 3 suggest that intervention during the first discretionary period had a moderately sizable effect on the exchange rate, and in the direction intended by the authorities. ${ }^{39}{ }^{40}$ The coefficient for the effect of contemporaneous intervention $(0.78)$ is statistically significant, and implies that a US\$ 30 million (sterilized) purchase (the average daily amount of intervention within this period) depreciated the value of the domestic currency by approximately 0.23 percent. ${ }^{41}$ That is, the intervention required to contemporaneously move the nominal exchange rate by 1 percent on a given day represented approximately 2 percent of the country's reserve money. Importantly, and given that during this period central bank operations were kept secret and were unannounced, the results suggest that transparency in central bank intervention policy was not a necessary condition for intervention to be effective.

The results in the second column of Table 3 also suggest that sterilized intervention operations had no statistically significant contemporaneous effect on exchange rate returns during the second episode of discretionary intervention. ${ }^{42}$ Instead, the results of the model points to the theoretically sensible finding that high and increasing interest rate differentials, positive domestic inflation surprises and improvements in sovereign creditworthiness (as represented by decreases in the EMBI spread) were key factors driving the appreciation of the peso during this period. The fit of the exchange rate model (R-square of 0.42) is significantly higher than in previous studies, indicating a high explanatory power for exchange rate changes during this period.

\footnotetext{
${ }^{38}$ The model seems to capture only a small fraction of the variance of the intervention variable as suggested by the R-square statistic, in particular during the first period. This may suggest that other variables not captured in the model — such as political factors - were also important. See Vargas (2005) for a discussion of political economy issues related to intervention.

${ }^{39}$ These results are consistent with Toro and Julio (2006), who use ultra-high frequency data to analyze the impact of intervention on exchange rate dynamics in Colombia between 2004 and 2006.

${ }^{40}$ Maximum likelihood estimation was carried out using the Berndt-Hall-Hall-Hausmann algorithm using Eviews 5.1 package. In all cases, the skewness and kurtosis of the standardized regression residuals indicate that the assumption of conditional normality in equation (2) does not hold. Therefore, robust standard errors using the method described in Bollerslev and Wooldridge (1992) were reported.

${ }^{41}$ The appreciation of the Colombian peso in 2005 was fairly moderate and less acute than the corresponding appreciation that took place in other countries in the region such as Brazil and Chile.

${ }^{42}$ This result is robust to modeling the $\operatorname{GARCH}(1,1)$ model with a different error distribution, such as the Student's t or the Generalized Error Distribution.
} 
Table 3. Impact of Central Bank Intervention on Exchange Rate Level

(GARCH Model: Mean Returns Equation)

\begin{tabular}{|c|c|c|}
\hline & $\begin{array}{r}\text { First Period } \\
\text { September 2004-March 2006 } \\
\end{array}$ & $\begin{array}{r}\text { Second Period } \\
\text { January 2007-April } 2007 \\
\end{array}$ \\
\hline$\beta_{0}$ (Lagged Dependent Variable) (t-1) & $\begin{array}{l}0.228 * * * \\
(0.07)\end{array}$ & $\begin{array}{l}0.148 \text { * } \\
(0.08)\end{array}$ \\
\hline \multicolumn{3}{|l|}{ Intervention Indicator } \\
\hline$\beta_{1}$ (Instrumented Amount of Dollar Purchases by Central Bank) ( $t$ ) & $\begin{array}{l}0.782 * * * \\
(0.29)\end{array}$ & $\begin{array}{l}0.055 \\
(0.09)\end{array}$ \\
\hline$\beta_{2}$ (Overnight Interest Rate Differential) (t) & $\begin{array}{l}-0.024 * * \\
(0.01)\end{array}$ & $\begin{array}{l}-0.371^{* *} \\
(0.16)\end{array}$ \\
\hline$\beta_{3}$ (Daily Change in EMBI Sovereign Spread) ( $t$ ) & $\begin{array}{l}1.287^{* * *} \\
(0.22)\end{array}$ & $\begin{array}{l}2.023 * * \\
(0.92)\end{array}$ \\
\hline \multicolumn{3}{|l|}{ Unexpected Component of Inflation Announcement } \\
\hline$\beta 4$ (Actual minus Expected Value of Inflation) (t-1) & $\begin{array}{l}0.286 * * * \\
(0.10)\end{array}$ & $\begin{array}{l}-0.464^{* \star *} \\
(0.08)\end{array}$ \\
\hline Dummy for Days with Automatic FX Intervention & Yes & Yes \\
\hline \multicolumn{3}{|c|}{ Diagnostics } \\
\hline $\begin{array}{l}\text { Log } L \\
\text { R-Squared } \\
\text { Included observations }\end{array}$ & $\begin{array}{r}-66.160 \\
0.150 \\
356\end{array}$ & $\begin{array}{r}-7.460 \\
0.430 \\
73\end{array}$ \\
\hline
\end{tabular}

Source: Author's calculations.

Note: This table reports estimation of the Mean Equation of the GARCH(1,1) model in equation (3)-(5) in the text. The dependent variable is the daily rate of change of the nominal exchange rate, in percent. The coefficient on the intervention variables measures the pecentage change in the exchange rate for a US\$100 million in foreign currency purchases. Asterisks denote significance of coefficients, with ${ }^{* * *},{ }^{* *}$ and ${ }^{*}$ indicating significance at the $1 \%, 5 \%$ and $10 \%$ level, respectively.

Exchange rates appear to have been responsive to announcements on economic news during both periods. Two results stand out. First, news on inflation announcements had a significant impact on exchange rate dynamics, suggesting that fundamentals also drive the exchange rate at higher frequencies. ${ }^{43}$ Second, the effect of these announcements was exactly the opposite across periods (Table 3). During the first period of intervention, higher-than-expected inflation was on average associated with a depreciation of the peso. During 2007, however, the sign on the unexpected inflation variable was negative and statistically significant, indicating that higher-than-expected inflation resulted in a strong currency appreciation (a reduction in the nominal exchange rate) the subsequent day. The point estimate is economically important: for example, if announced inflation was 1 percentage point above expectations during the second period, the estimated effect was

\footnotetext{
${ }^{43}$ The systematic relationship between the surprise component of macroeconomic releases and one-day exchange rate changes is noteworthy, given that the literature has pointed out that this connection is weak and hard to detect (Edison, 1997).
} 
an appreciation of the peso of almost half a percent the next day. The results thus indicate that during the second period, "bad news" about inflation - inflation higher than expected - was "good news" for the nominal exchange rate (that is, the exchange rate appreciated following this news). ${ }^{44}$

The stark differences across periods in the high frequency response of exchange rates to inflation surprises, provides new insights into the effectiveness of central bank intervention. During the first period of discretionary intervention, the Colombian economy was recovering from a recession and output gap was on average negative (Figure 3). As such, market participants did not seem to price in that unexpectedly high inflation announcements would prompt monetary policy tightening. ${ }^{45}$ During the second period of discretionary intervention, however, the economy was overheating and headline inflation was significantly above the 3.5-4.5 percent target range for end-2007 (see Figure 4). Thus, the fact that the peso consistently and significantly appreciated in response to unexpectedly high inflation suggests that markets apparently believed that the BdR would react to such news by increasing interest rates. ${ }^{46}$ Consistent with the notion that exchange rates are forward looking asset prices that react to changes in the market's expectation of future fundamentals, the prospect of an increase in domestic interest rates made Colombian assets more attractive, inducing an immediate dollar depreciation (peso appreciation) to equilibrate the asset market. This market reaction provides insight into the reasons why intervention was ultimately not effective in 2007: markets expected that monetary policy would remain committed to the goal of reducing inflation, even if that meant increasing interest rates and-by encouraging more capital inflows - undoing intervention efforts.

\footnotetext{
${ }^{44}$ Results for the second period of intervention are consistent with the recent findings by Clarida and Waldman (2007), who look at the reaction of nominal exchange rates to inflation surprises using intra-daily data across 10 countries. The authors show that if a central bank has an inflation target that it implements via a Taylor rule, an unexpectedly high inflation announcement leads to a stronger domestic currency.

${ }^{45}$ Consistent with market expectations, repo rates were reduced by an additional 50 basis points during 2005 (see Figure 2).

${ }^{46}$ During the first discretionary intervention episode, 75 percent of the monthly announcements of inflation were higher than what the market was expecting. The average value of these positive inflation surprises was 0.25 percent. During the second intervention episode, however, all four inflation announcements between January 15 and April 30, 2007 were above market expectations and the average value of the inflation surprises was five times higher than during the first period (1.3 percent).
} 
Figure 3. Output Gap in Colombia

(In percentage deviation from trend, quarterly frequency)

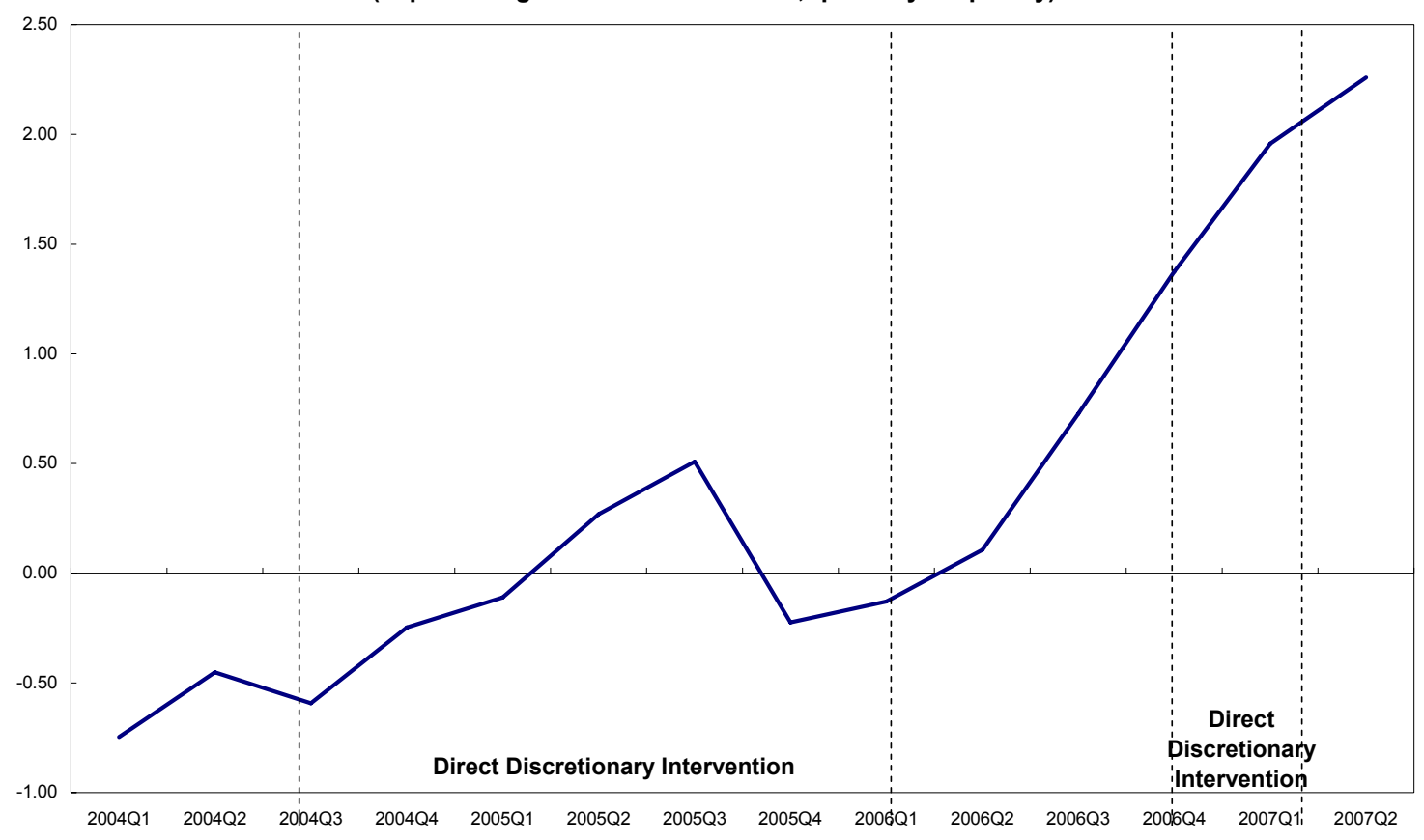

Sources: Banco de la República; and author's calculations.

Figure 4. Evolution of Inflation and Inflation Expectations vis-à-vis the Inflation Target

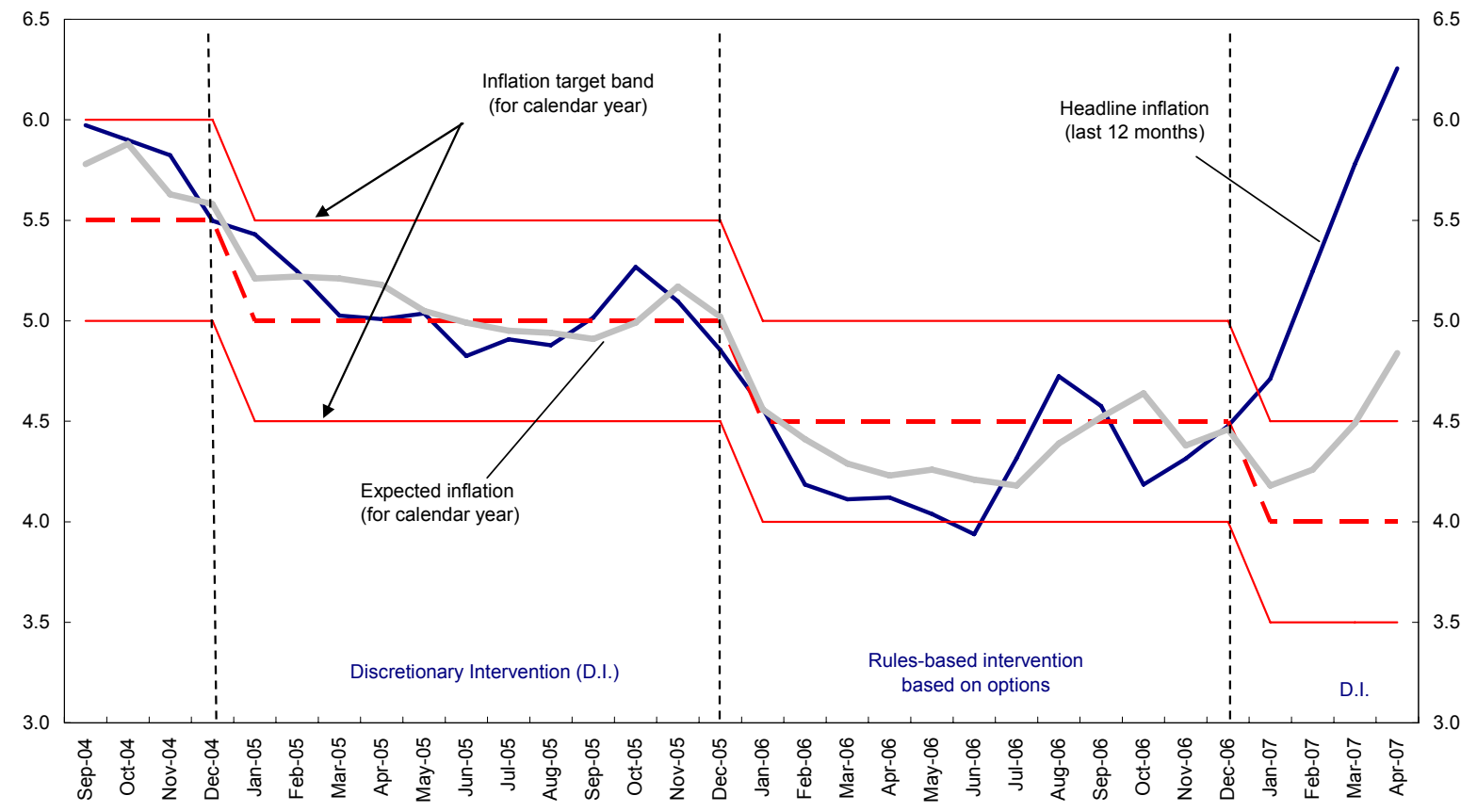

Sources: Banco de la República; and author's calculations. 
Also of interest is how central bank intervention affects exchange rate volatility. Volatility often reflects, among other things, uncertainty in economic policies and other fundamental determinants of exchange rates, which the market may be struggling to price accurately. As indicated by Domínguez (1998), central bank intervention is expected to reduce volatility as long as intervention is both credible and unambiguous. The results of Table 4 are consistent with this hypothesis. During the first period, BdR intervention had a stabilizing effect on the exchange rate. Controlling for other factors affecting short-term exchange rate volatility, the results indicate that BdR's discretionary intervention had the un-intended consequence of dampening the volatility of exchange rate returns. ${ }^{47}$ This empirical finding is noteworthy, given that the smoothing effect of intervention on exchange rate volatility is at odds with most of the intervention literature for developing economies. In contrast, during the second period, official discretionary intervention had no discernible impact on exchange rate volatility. ${ }^{48}$

In Table 5, I capture the dynamics of the short-term effects of intervention on the level of exchange rates by including the contemporaneous value of intervention and its four lags. Results indicate that the first day of official intervention was the most effective in moving the exchange rate in the desired direction, while the positive effects in successive days were statistically insignificant. That is, there is no evidence that the dynamic effect of intervention was greater than its contemporaneous impact. Rather, estimates suggest a strong mean reversion in exchange rate returns after an intervention operation: almost 40 percent of the contemporaneous effect was reversed in two days. This meant that significant amounts of foreign currency purchases were required to have a quantitatively important impact on the nominal exchange rate. During the second intervention episode, however, BdR's intervention was ineffective in influencing exchange rates at any horizon-confirming the results found above. ${ }^{49}$

\footnotetext{
${ }^{47}$ In unreported results, I find that the stabilizing effect on the exchange during the first intervention period was stronger after December 20, 2004, when the BdR reduced interest rates and simultaneously announced that interventions would continue indefinitely, with no predetermined amount or duration.

${ }^{48}$ During the first period, monthly inflation announcements led to an economically significant drop in conditional volatility of exchange rates in the subsequent day. Interestingly, during the second period foreign exchange market uncertainty did not decrease in the day following the official announcement of inflation. As noted in Footnote 45, during the second period, the actual inflation rates announced were systematically underestimated by the market, possibly leading to major revision in expectations following these official announcements.

${ }^{49}$ It is telling that - in spite of massive foreign currency purchases by the BdR that reached 4.53 billion dollars (39 percent of monetary base) in the first four months of 2007- the exchange rate continued its steep appreciation path, the second-highest among emerging markets during this period.
} 
Table 4. Effect of Central Bank Intervention on Volatility of Exchange Rate (GARCH Model: Conditional Variance Equation)

\begin{tabular}{|c|c|c|}
\hline & $\begin{array}{r}\text { First Period } \\
\text { September 2004-March } 2006 \\
\end{array}$ & $\begin{array}{r}\text { Second Period } \\
\text { January 2007-April } 2007 \\
\end{array}$ \\
\hline$\alpha_{0}(\mathrm{GARCH}$ Term) & $\begin{array}{l}0.560 * * * \\
(0.13)\end{array}$ & $\begin{array}{l}0.544^{* * *} \\
(0.23)\end{array}$ \\
\hline$\alpha_{1}$ (Squared Innovation) & $\begin{array}{l}0.210 * * * \\
(0.08)\end{array}$ & $\begin{array}{l}0.098 \\
(0.09)\end{array}$ \\
\hline \multicolumn{3}{|l|}{ Intervention Indicator } \\
\hline$\beta 1$ (Actual Amount of Dollar Purchases) (t) & $\begin{array}{l}-0.019 * * * \\
(0.01)\end{array}$ & $\begin{array}{r}-0.009 \\
(0.01)\end{array}$ \\
\hline$\beta_{2}$ (Overnight Interest Rate Differential) & $\begin{array}{r}-0.004 \\
(0.00)\end{array}$ & $\begin{array}{r}-0.003 \\
(0.03)\end{array}$ \\
\hline$\beta_{3}$ (Daily Change in EMBI Sovereign Spread) & $\begin{array}{l}0.095 \\
(0.14)\end{array}$ & $\begin{array}{r}-0.153 \\
(0.16)\end{array}$ \\
\hline \multicolumn{3}{|l|}{ Unexpected Component of Inflation Announcement } \\
\hline B4 (Actual minus Expected Value of Inflation, in absolute terms) (t-1 & $\begin{array}{l}-0.223 * * * \\
(0.04)\end{array}$ & $\begin{array}{r}-0.028 \\
(0.02)\end{array}$ \\
\hline Fixed Effects for Days-of-the Week and Post-Holiday Trading Days & Yes & Yes \\
\hline Dummy for Days with Automatic FX Intervention & Yes & Yes \\
\hline
\end{tabular}

Source: Author's calculations.

Note: This table reports estimation of the Mean Equation of the GARCH(1,1) model in equation (3)-(5) in the text. The dependent variable is the daily rate of change of the nominal exchange rate, in percent. The coefficient on the intervention variable measures the pecentage change in the exchange rate for a US $\$ 100$ million in foreign currency purchases. Asterisks denote significance of coefficients, with ${ }^{* * *}$, ${ }^{* *}$ and ${ }^{*}$ indicating significance at the $1 \%, 5 \%$ and $10 \%$ level, respectively. 
Table 5. Dynamic Effects of Central Bank Intervention (Mean Returns Equation)

\begin{tabular}{lcr}
\hline & First Period & Second Period \\
& September 2004-March 2006 & January 2007-April 2007 \\
\hline$\beta_{0}$ (Lagged Dependent Variable) (t-1) & $0.288 * * * 173$ & $(0.11)$ \\
& $(0.06)$ & \\
Contemporaneous Effect & & 0.098 \\
$\beta_{1}$ (Central Bank Intervention) (t) & & $(0.13)$ \\
& $1.000 * * *$ & $(0.23)$ \\
Persistence Effects & & -0.035 \\
$\beta_{11}$ (Central Bank Intervention) (t-1) & & $(0.15)$ \\
& & -0.028 \\
$\beta_{12}$ (Central Bank Intervention) (t-2) & 0.066 & $(0.09)$ \\
& $(0.17)$ & 0.055 \\
$\beta_{13}$ (Central Bank Intervention) (t-3) & $-0.414 * * *$ & $(0.10)$ \\
$\beta_{14}$ (Central Bank Intervention) (t-4) & $(0.14)$ & 0.012 \\
& & $(0.09)$ \\
\hline Log L & 0.018 & $(0.06)$ \\
\hline
\end{tabular}

Source: Author's calculations.

Note: This table reports estimation of the Mean Equation of the $\operatorname{GARCH}(1,1)$ model in equation (3)-(5) in the text, augmented with four lags of the instrumented indicator of central bank intervention as regressors. The estimated model also includes a constant, interest rate differential, EMBI spread, dummies for days-of-the-week effect and a dummy for automatic FX intervention (which are not shown). Asterisks denote significance of coefficients, with ${ }^{* * *},{ }^{* *}$ and ${ }^{*}$ indicating significance at the $1 \%, 5 \%$ and $10 \%$ level, respectively.

In Appendix II, I report on a number of sensitivity tests that probe the central results regarding the treatment for endogeneity and the possibility that the "surprise" element of BdR's interventions (rather than its predicted component) had a significant effect on exchange rates during the second period. The results of such tests are virtually identical to those reported above, and yield the same inferences regarding the effectiveness of discretionary intervention across periods.

\section{Potential Policy Lessons}

\section{A. Limits to Intervention Imposed by the Inflation Targeting Regime}

The coherence between the intervention policy and inflation objectives was a critical factor underlying the effectiveness of discretionary intervention during the first period. Purchases of international reserves were made in the context of a negative output gap and decreasing inflation rates. For this reason, inflation expectations were not adversely affected by the intervention in the foreign exchange market, and the BdR achieved the 
inflation targets with remarkable precision (see Figure 4). Because macroeconomic objectives were well aligned, foreign currency purchases credibly signaled an easing of monetary policy - even if intervention operations were not publicly announced. In this way, foreign currency intervention and monetary policy maintained target consistency, which helped increase both the effectiveness of intervention and the credibility of inflation targets (Figure 5). ${ }^{50}$

Figure 5. Credibility of the Inflation Target (Survey done on April of each year)

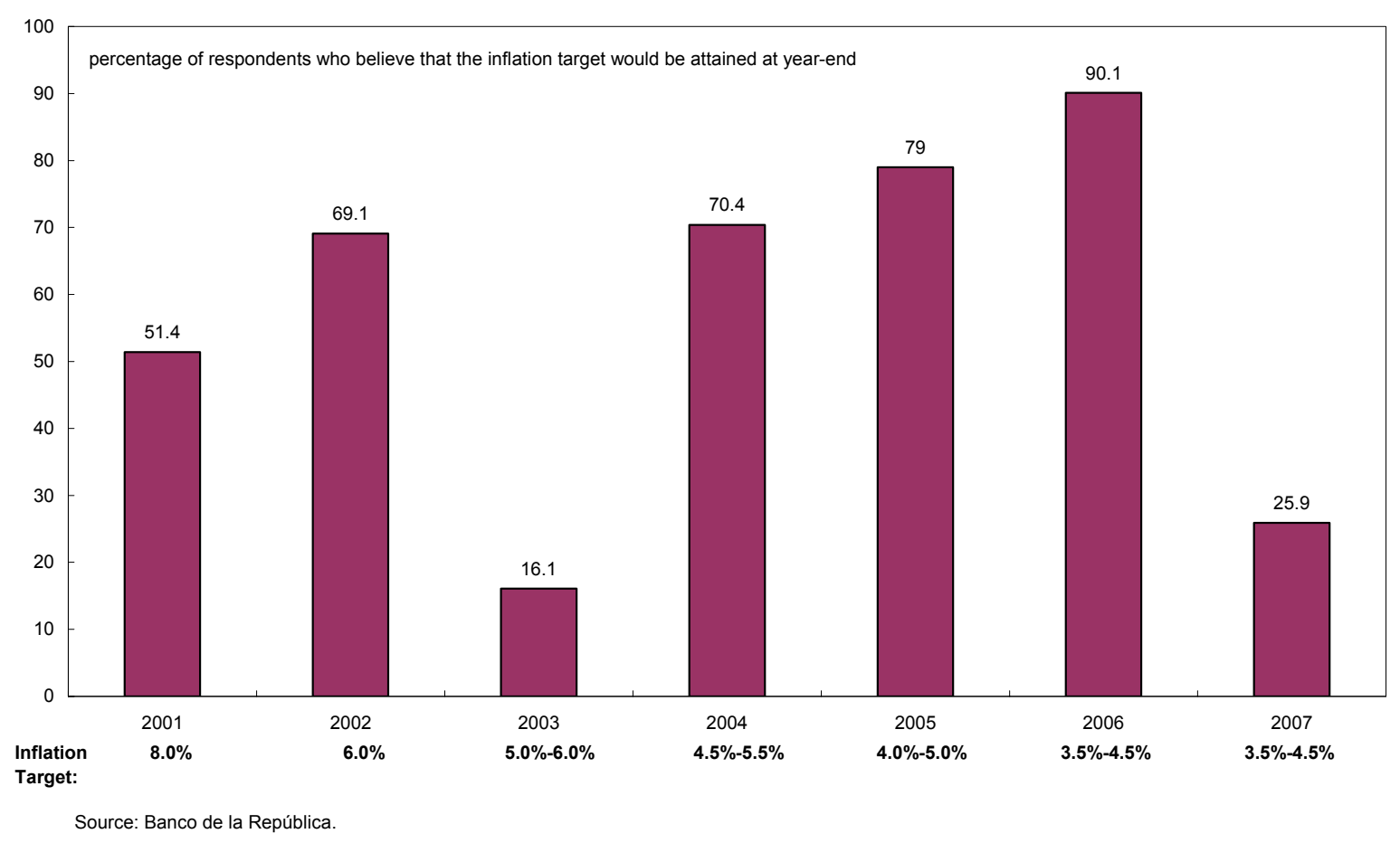

During the second period, however, monetary and exchange rate policy objectives conflicted and intervention was ineffective. To stem the appreciation of the peso, the BdR intervened aggressively, while it was at the same time steadily increasing interest rates to cope with inflation pressures. Predictable rate increases, in turn, attracted more capital inflows, exacerbating appreciation pressures. Moreover, monetary and exchange rate policies worked at cross-purposes: resisting currency appreciation blunted the passthrough channel that would have provided welcome help in offsetting higher international food prices.

In this environment, markets perceived that the policy of large-scale foreign currency purchases was unsustainable and inconsistent with meeting the BdR's inflation target, which may have contributed to inflation expectations being above the inflation target

${ }^{50}$ Toro and Julio (2006) provide additional support for this conclusion. 
ceiling (see Figure 4). ${ }^{51}$ Foreign investors, trusting that the Central Bank would eventually focus on taming inflation (and eventually let the exchange rate appreciate), took unprecedented amounts of short dollar positions at short maturities in the on-shore forward market (Figure 6). ${ }^{52}$ The turnover value in peso forwards bought by off-shores to local banks increased more than three times between end-2006 to its peak in March 2007. The size and speed of execution of this leveraged market positions substantially reduced the ability of the central bank to influence exchange rate market conditions by buying international reserves.

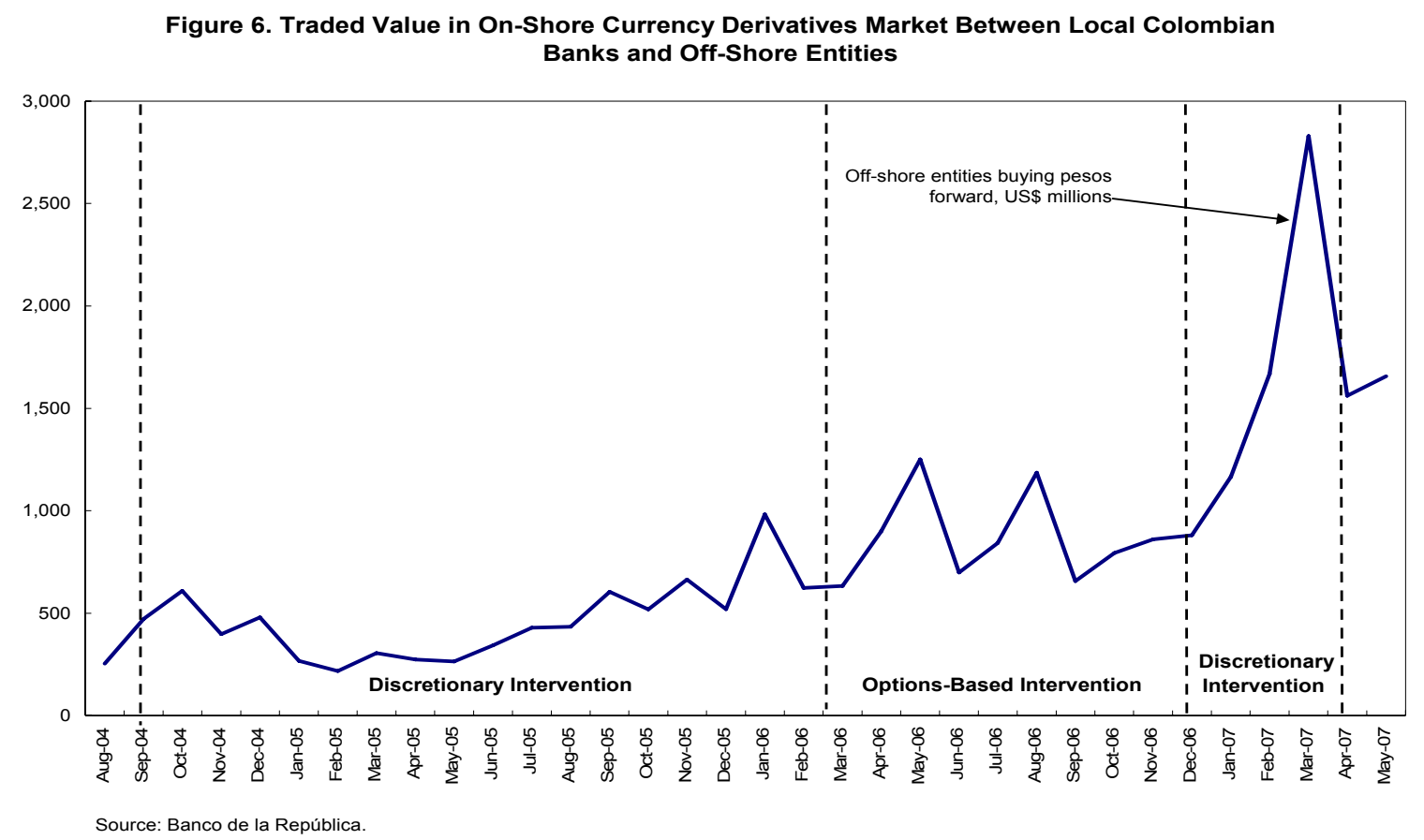

\section{B. The Role of Derivatives Markets in Blunting Central Bank Intervention}

Colombia's experience also highlights the practical limits to sterilization of reserve accumulation when the macroeconomic cycle calls for tightening monetary policy. With the BdR undertaking large-scale intervention in the first months of 2007, the BdR quickly

\footnotetext{
${ }^{51}$ The rapid increase in inflation in early 2007—caused in part by supply shocks - may have made it difficult to detect the incompatibility between these goals. Inflation in Colombia was rising in early 2007, also due to food price shocks. When inflation is rising, it may not always be clear that the cause is excess demand or a temporary supply shock. If it is a supply shock, then intervention may not be perceived as incompatible with achieving the inflation target. Economic agents, however, appeared to have believed that excess demand pressures were present (especially coming from Venezuela), given the increase in inflationary expectations.

${ }^{52}$ Offshore players shorted the dollar in the forward market to gain exposure to the Colombian peso, and indirectly to the prevailing interest rate differential. Kamil and Reveiz (2008) analyze in detail the role of derivatives markets as a conduit for this carry trade, and discuss its policy implications.
} 
reduced its stock of treasury bills and, by mid-march 2007, was soon close to a position where it would no longer be a net creditor to the financial system (Figure 7). A net creditor position is regarded as more desirable for reasons of monetary control: in practice, a central bank is better positioned to move short-term interest rates to its desired level if the monetary authority is a net lender of liquidity to the financial sector. Thus, investors knew that if the BdR became a net debtor of the banking system, this would greatly weaken its ability to conduct monetary policy, other things remaining equal. Under this net debtor scenario, the authorities would be forced to discontinue intervening and the exchange rate would appreciate on impact. ${ }^{53}$

Figure 7. Net Creditor Position of the Colombian Central Bank vis a vis the Financial Sector and Behavior of Interest Rates

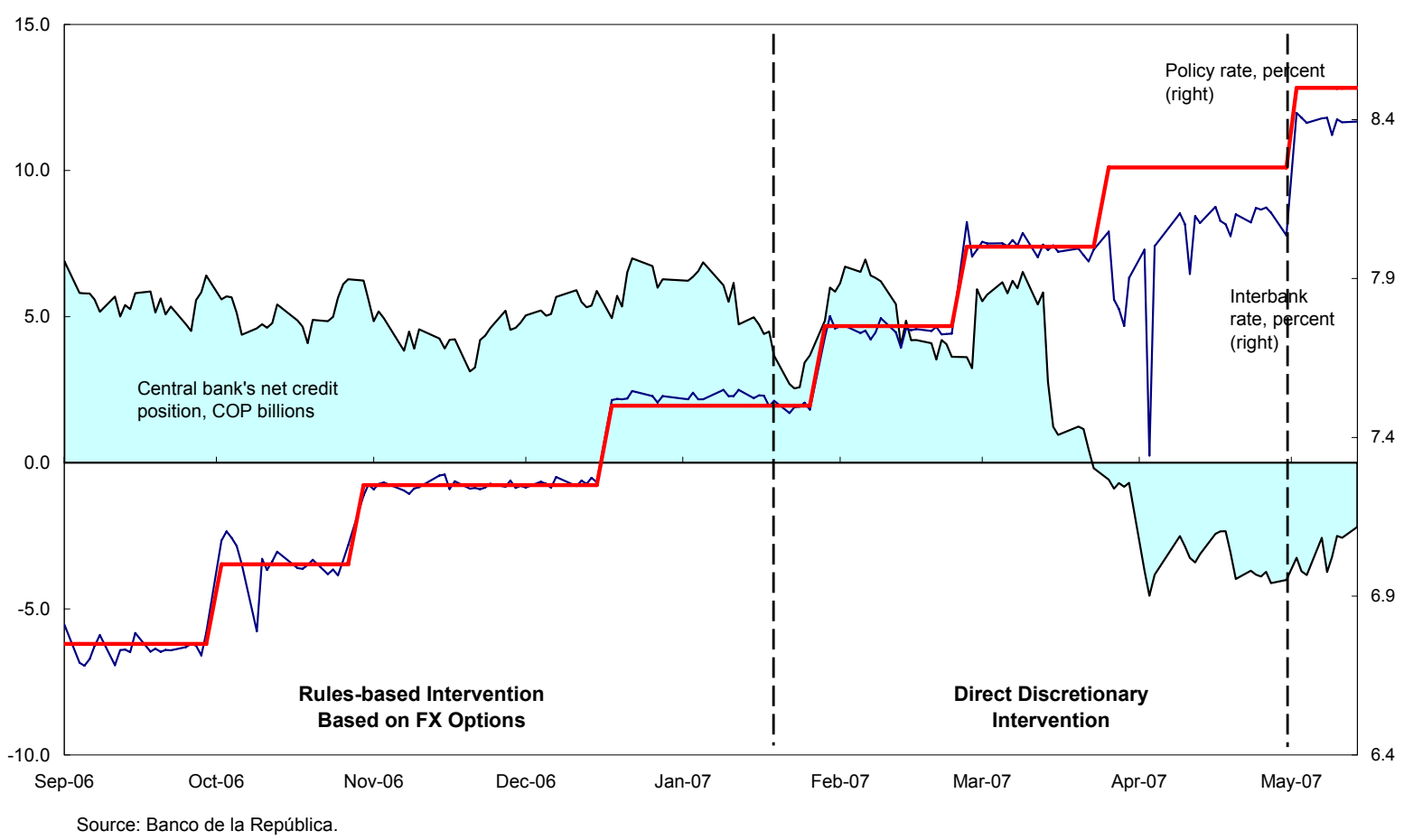

Predicting that sterilization efforts would become unsustainable, offshore entities speculated heavily on a real exchange rate appreciation by building-up large longpositions in pesos through the onshore forward market (see Figure 6 above). ${ }^{54}$ Due to

\footnotetext{
${ }^{53}$ As opposed to the information on intervention operations, the net creditor position of the BdR is updated daily in the BdR's official website. Thus, as the BdR soon approached a position in which it would become a net debtor, financial markets may have perceived that the scope for additional intervention would be coming to an end.

${ }^{54}$ Speculative demand for the peso was also buttressed by the prospect that the underlying forces putting upward pressure on the real exchange rate (such as the improvement in the security situation, better terms of trade and strong inflows of foreign direct investment) were expected to persist over time.
} 
prudential reasons and/or risk aversion, domestic banks giving the bid to foreign speculators balanced their short peso position by taking off-setting contracts (real o synthetic) with other counterparties. Yet, since the banking system as a whole attempted to do the same, the ultimate counterparty was the BdR, as it was the only market participant willing to take the long U.S. dollar risk. ${ }^{55}$

Quite clearly, the sudden burst of derivatives trading that occurred on March 30, 2007 (see the third in Figure 8) led to large-scale purchases of foreign currency by the BdR and a massive injection of liquidity. ${ }^{56}$ This "tipped-over" the Central Bank into a net debtor position, making it more difficult to control inter-bank rates. ${ }^{57}$ This is evident in the behavior of policy and inter-bank interest rates in Figure 7. While the average inter-bank rate tracked very closely the reference rate until the end of March 2007, the relationship weakened after that. Indeed, the massive injection of liquidity due to foreign currency purchases became fully apparent in the money market since the beginning of April, as the inter-bank interest rate drifted below and away from the BdR's lending rate. This stifled the primary transmission channel of monetary policy and layed the groundwork for the demise of intervention efforts a month later. ${ }^{58}$

These developments suggest that inflation-targeting regimes may indeed be vulnerable to speculative attack - but one that appreciates the currency. One of the major advantages of inflation targeting, it is often claimed, is that this monetary framework is immune to such attacks. The logic is that a run on reserves can be averted because the central bank can simply let the exchange rate go (depreciate). However, in the case where the authorities need to tighten monetary policy to meet its inflation objectives, they will also need to allow the exchange rate to "go"- but in this case, allow it to appreciate. If not, as

\footnotetext{
${ }^{55}$ Lall (1997) describes a theoretical model that resembles the experience of Colombia but in reverse, where forward markets are the main channel used by speculators to mount a speculative attack against the domestic currency in a fixed exchange rate regime.

${ }^{56}$ That day, off-shore entities bought the equivalent of almost US\$ 600 million in pesos forward, seven times the daily average in the previous six months. This attack against the dollar which was ultimately met by BdR's foreign currency purchases in the spot market of US\$740 million, or 7 percent of the monetary base (in a single day).

${ }^{57}$ The possibility that large scale foreign currency purchases could eventually turn the BdR from a net provider of short-term liquidity to being a net borrower vis-à-vis the financial sector was correctly anticipated in Vargas (2005).

${ }^{58}$ To preserve the control of monetary conditions, the BdR opened its own deposit facility on April 2, 2007 to mop up the excess liquidity from the financial system. Finding it increasingly difficult, however, to offset their massive purchases, the authorities decided to stop intervening on April 30, 2007. While in theory the BdR could have found additional ways of regaining control of the inter-bank rate (e.g., a special allotment of treasury bills or issuance of its own long-term bond), in practice, these were not conceived as options by monetary authorities. Since May 2007, BdR's involvement in the foreign exchange market has been limited to controlling exchange rate volatility through the options mechanism.
} 
the case of Colombia demonstrates, the currency will be open to speculative attacks - in this case, against the dollar. ${ }^{59}$

The Colombian experience demonstrates two noteworthy characteristics concerning this "speculative attack" that may be instructive for other emerging market countries. ${ }^{60}$ First, such attacks may occur in the derivatives market rather than in the spot market, as speculators leverage massive bets on appreciation of the peso. ${ }^{61} \mathrm{With}$ financial systems in emerging markets growing in depth and sophistication, inconsistencies in monetary policy objectives are eventually arbitraged in the derivatives markets, thereby limiting the effectiveness of intervention. Secondly, the ability of authorities to resist the attack is not determined by the level of reserves, as in the first-generation crisis models (indeed, they accumulate international reserves). Rather, what can occur is a run is on the central bank's net creditor position vis-à-vis the financial system. ${ }^{62}$

In summary, the Colombian experience shows that large, persistent and one-sided central bank foreign exchange purchases that that go against the perception of the majority of market has little possibility of success. In such circumstances, intervention can actually lead to greater financial instability, as investors engage in one-way bets against the central bank in the expectation of a high return once the official resistance to the exchange rate adjustment is overpowered.

\footnotetext{
${ }^{59}$ Kumhof, Li and Yang (2007) analyze a small open economy model under inflation targeting, and show that an inflation-targeting regime can be also vulnerable to speculative attacks. In their model, however, the central bank intervenes to avert a currency depreciation and the attack depletes central bank's reserves.

${ }^{60}$ These special features set them apart from traditional first-generation currency crisis models (Krugman, 1979).

${ }^{61}$ It is important to note that the strength of such a "speculative attack" depends on how attractive the country is as a destination for carry trade vis-à-vis other emerging market countries at that point in time. In the case of Colombia in 2007, conditions were very favorable for such inflows, with correspondingly large effects.

${ }^{62}$ Much of the literature emphasizes that the high quasi-fiscal costs of intervention is what ultimately limits sterilization efforts. In Calvo (1991) and Calvo, Leiderman and Reinhart (1993), for example, it is argued that resisting currency appreciation keeps domestic money market interest rates high, attracting more inflows and thus continuously increasing the need for sterilization. Eventually, the cost of sterilization rises to unsustainable levels and must be abandoned.
} 
Figure 8. Derivative Markets Can Blunt Central Bank Intervention Operations When Policies Are Inconsistent

Net Creditor Position BdR

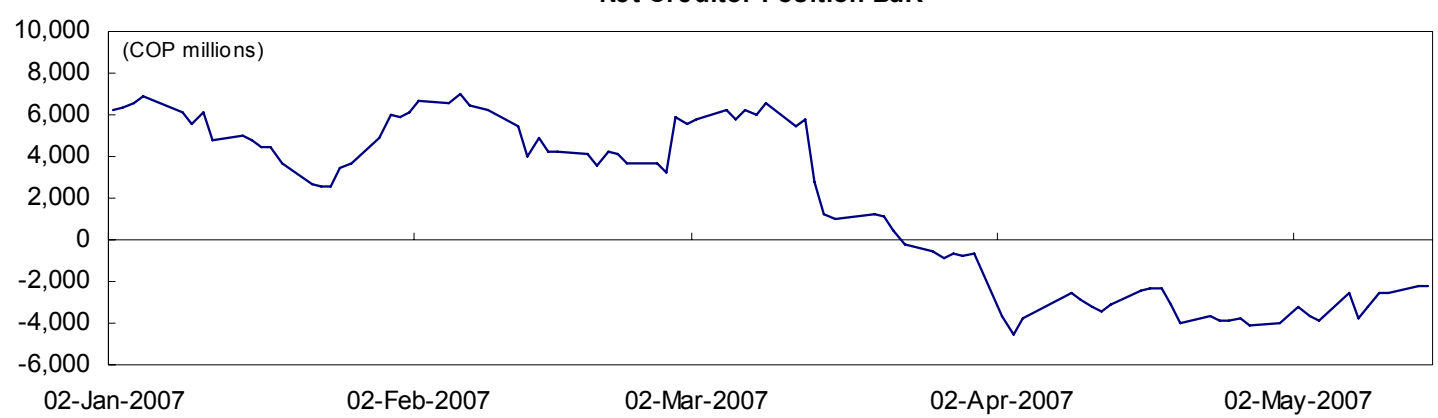

Discretional Intervention

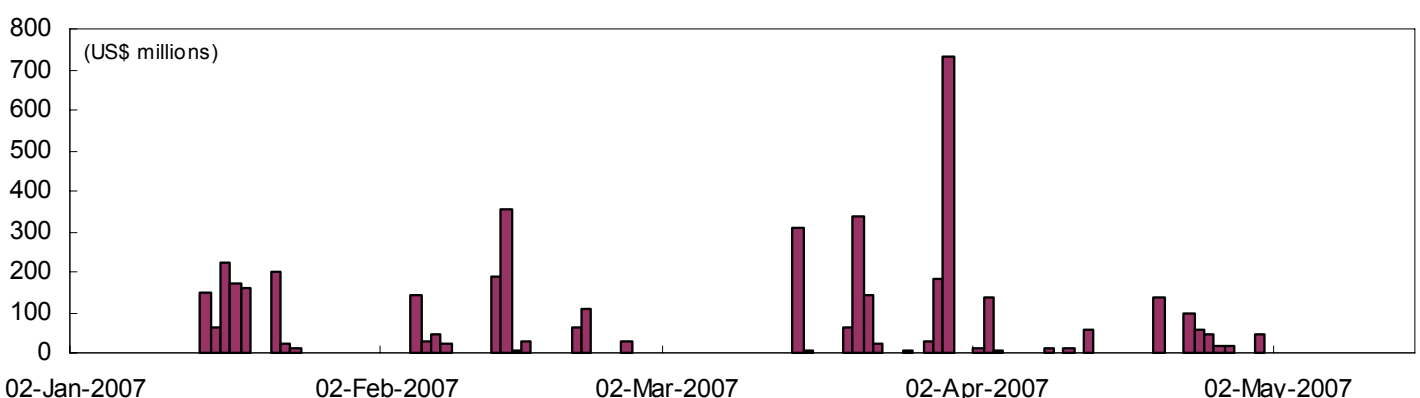

Volume Traded on Peso Long Positions by Offshore Entities in Local Currency Derivative Markets

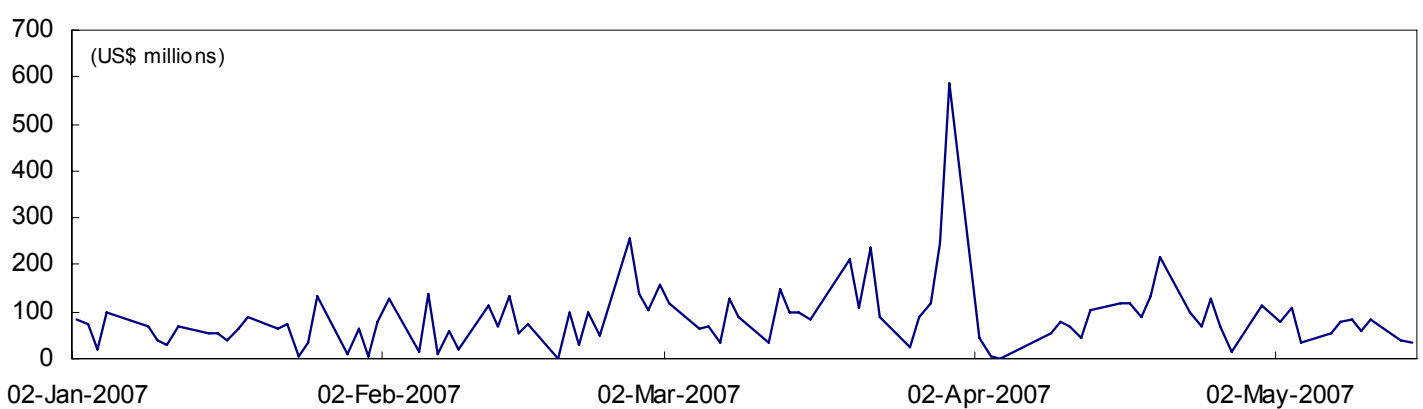

Interbank Rate (Weighted Average)

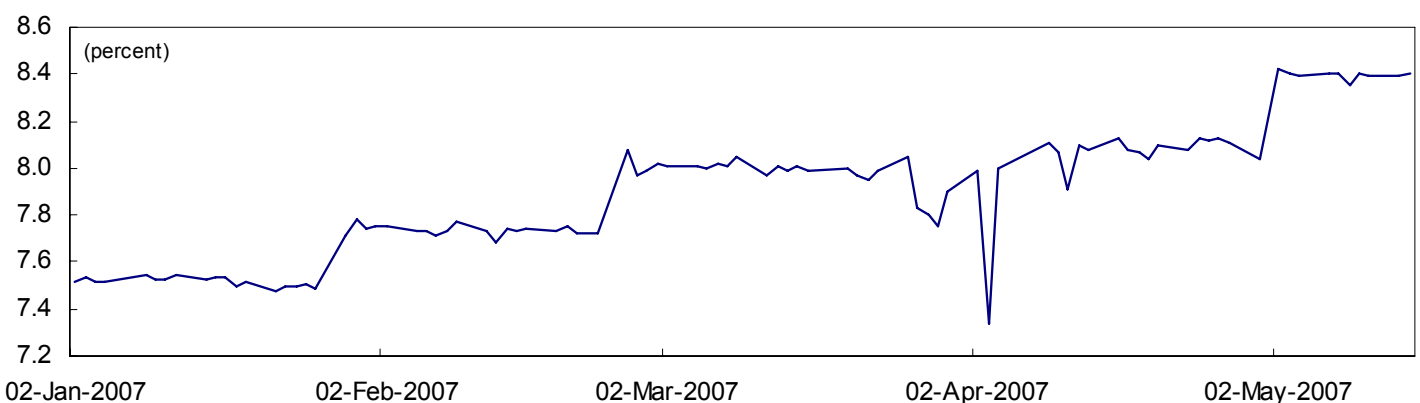

Source: Banco de la República. 


\section{ConcLusions}

How effective is central bank intervention in influencing the nominal exchange rate in emerging markets? While an extensive literature exists on this subject for advanced economies - with mixed results - much less is known about foreign exchange intervention effectiveness as an independent policy tool in emerging markets. This paper adds to this literature by examining Colombia's experience with central bank foreign exchange intervention between 2004 and 2007. During most of this period, the BdR engaged in large-scale, discretionary purchases of foreign exchange to resist appreciation of the domestic currency, making it an interesting case study for assessing the efficacy of such efforts.

Our results suggest that the effectiveness of BdR intervention was substantially different across the two periods of discretionary intervention. During the first period of unannounced discretionary intervention (September 2004-March 2006), we find statistically significant evidence that intervention affected the level of the exchange rate in the intended direction. Moreover, foreign exchange intervention moderated the appreciation of the peso vis-à-vis the U.S. dollar without undermining the BdR's ability to meet the inflation target. Thus, Colombia's experience between 2004 and 2006 indicates that an inflation-targeting regime can be credible and effective even though the exchange rate regime is not an entirely clean float.

The Colombia experience in the first half of 2007, however, illustrates the limits of intervention as an independent policy instrument. During the second period of discretionary intervention, there was no detectable impact on exchange rate markets, as intervention was ineffective in moving the exchange rate in the desired direction. During this period, the BdR was torn between a concern for price stability, on the one hand, and concern over the rapid pace of appreciation of the exchange rate, on the other. In this environment, markets perceived the BdR as pursuing two mutually inconsistent goals. The ineffectiveness and inconsistency of intervention, thus, became mutually reinforcing. I show that in this case, central bank intervention can be destabilizing, by causing traders to speculate against the central bank (i.e., increasing leveraged long peso positions in derivative markets).

In summary, this study provides strong support for the proposition that intervention cannot systematically influence the level of the exchange rate when intervention creates a conflict with other goals of monetary policy that the public perceives as overriding. Paradoxically, the BdR's perceived strong commitment to inflation actually undermined its ability to influence the exchange rate: the market most likely believed the BdR would never subordinate its inflation objective to concerns about the exchange rate. In this context, derivative markets appear to have played an important role in exploiting any inconsistencies in the objectives of monetary policy, blunting the effectiveness of intervention during the latter period. 
Additional research on the effects of intervention would be useful. Better data availability (especially at daily frequencies) and continued research into the motives, strategies, and channels for conducting foreign exchange market operations intervention in emerging markets countries could help provide more guidance on the appropriateness and effectiveness of intervention strategies. 


\section{APPENDIX I}

Table A1. Summary Statistics on the Unconditional Distribution of Daily Exchange Rate Returns

\begin{tabular}{lcc}
\hline & \multicolumn{2}{c}{ Regimes of Un-Announced Discretionary Intervention } \\
\cline { 2 - 3 } & First Period & $\begin{array}{c}\text { Second Period } \\
\text { January 2007-April 2007 }\end{array}$ \\
\hline Daily exchange rate statistics & & 0.01 \\
Mean (percent) & -0.03 & 0.07 \\
Variance (percent) & 0.17 & 0.04 \\
Skewness 1/ & 0.82 & -0.02 \\
Kurtosis & 9.11 & 23.86 \\
$Q_{\Delta s}(20) 2 /$ & 76.60 & 16.34 \\
$Q_{\Delta s 2}(20)$ & 349.20 & 2006 \\
\hline
\end{tabular}

Sources: Author's calculations based on data provided by the Banco de la República.

$1 /$ The kurtosis statistic is normalized so that a value of zero corresponds to the normal distribution

2/ $Q_{\Delta s}(20)$ and $Q_{\Delta s 2}(20)$ are Ljung-Box tests tests for high-order serial correlation for the returns and square returns up to the 20th lag, respectively. 


\section{Appendix II: Robustness Tests}

\section{Endogeneity}

A fundamental assumption of our analysis so far is that the amount of dollars bought by the BdR on a given day depends on past exchange rate returns, but is independent of movements in the exchange rate within that day. Admittedly, this is a strong identifying assumption, as it rules out the possibility that the BdR could have acted strategically by also taking into account the intraday evolution of the exchange rate in deciding how much to intervene. If this were the case, aggregate daily interventions and exchange rate changes would simultaneously determine each other, and thus estimates of the effect of central bank intervention would be biased downwards. ${ }^{63}$

Unfortunately, the exact timing and magnitudes of BdR's intervention in foreign exchange markets are not available at an intra-daily frequency. Data are available, however, on the opening exchange rates quotes each day from the Colombian foreignexchange electronic transactions system, known as SET-FX. Given that exchange rates are quoted at the beginning of the trading day while intervention data is reported at the close of the day, exchange rate returns at time $t$ (the percentage change in opening prices between $t$ and $t-1)$ are predetermined with respect to the amount of intervention at $t$. I exploit this differential timing to attenuate simultaneity problems and check the robustness of the baseline results. ${ }^{64}$

Table A.2 re-estimates the impact of BdR's intervention on exchange rate returns for both periods, using opening exchange rates quotes to measure daily exchange rate returns. ${ }^{65}$ Results are virtually identical to the benchmark estimates presented in Table 3 in the text, except that the positive impact of central bank intervention on exchange rate returns during the first discretionary period is somewhat lower. For the second period, I again fail to detect a significant effect of intervention on exchange rate levels, confirming the baseline result that intervention was not a useful short-term policy instrument for exchange rate management during 2007.

\footnotetext{
${ }^{63}$ Using a novel identification strategy, Kearns and Rigobon (2005) exploit exogenous structural breaks in the Japanese and Australian authorities' intervention strategies to estimate the effects of central bank intervention. Their identification method, however, hinges crucially on the assumption that the parameters of the authorities' intervention reaction function are stable across periods - something that is very difficult to justify in the Colombian case in light of the evidence presented in Section V.

${ }^{64}$ The same empirical strategy is used in Naranjo and Nimalendran (2000).

${ }^{65}$ As in the previous section, I also use a two-stage instrumental variable model based on estimates of the BdR's reaction function. Results from the first-stage are available upon request.
} 
Table A.2 Effects of Central Bank Intervention: Robustness Test for Endogeneity Concerns (Mean Returns Equation)

\begin{tabular}{|c|c|c|}
\hline & $\begin{array}{r}\text { First Period } \\
\text { September 2004-March 2006 } \\
\end{array}$ & $\begin{array}{r}\text { Second Period } \\
\text { January 2007-April } 2007 \\
\end{array}$ \\
\hline$\beta_{0}$ (Lagged Dependent Variable) (t-1) & $\begin{array}{r}-0.095 \\
(0.07)\end{array}$ & $\begin{array}{r}-0.130 \\
(0.10)\end{array}$ \\
\hline \multicolumn{3}{|l|}{ Intervention Indicator } \\
\hline$\beta_{1}$ (Instrumented Amount of Dollar Purchases by Central Bank) (t-1) & $\begin{array}{l}0.488 * \\
(0.29)\end{array}$ & $\begin{array}{l}0.067 \\
(0.07)\end{array}$ \\
\hline$\beta_{2}$ (Overnight Interest Rate Differential) (t-1) & $\begin{array}{l}-0.027 * \\
(0.01)\end{array}$ & $\begin{array}{l}-0.413 \text { *** } \\
(0.14)\end{array}$ \\
\hline$\beta_{3}$ (Daily Change in EMBI Sovereign Spread) (t-1) & $\begin{array}{l}1.609 * * * \\
(0.29)\end{array}$ & $\begin{array}{l}3.868^{* * *} \\
(0.17)\end{array}$ \\
\hline $\begin{array}{l}\text { Unexpected Component of Inflation Announcement } \\
\beta 4 \text { (Actual minus Expected Value of Inflation) (t-1) }\end{array}$ & $\begin{array}{l}0.272 \\
(0.31)\end{array}$ & $\begin{array}{l}-0.333^{* * *} \\
(0.12)\end{array}$ \\
\hline Dummy for Days with Automatic FX Intervention & Yes & Yes \\
\hline \multicolumn{3}{|c|}{ Diagnostics } \\
\hline $\begin{array}{l}\log L \\
\text { R-Squared } \\
\text { Included observations }\end{array}$ & $\begin{array}{r}-28.001 \\
0.088 \\
356\end{array}$ & $\begin{array}{r}-7.581068 \\
0.585 \\
73\end{array}$ \\
\hline
\end{tabular}

Source: Author's calculations.

Note: This table reports estimation of the Mean Equation of the GARCH(1,1) model in equation (3)-(5), modified to account for the timing in exchange rate quotes as discussed in Section $\mathrm{VI}$ in the text. Explanatory variables are lagged one period because exchange rates are quoted at the beginning of the trading day, while intervention is as of the end of the business day, and interest rate and differential and EMBI spread are calculated as averages within the day. The coefficient on the intervention variable measures the pecentage change in the exchange rate for a US $\$ 100$ million in foreign currency purchases. Asterisks denote significance of coefficients, with ${ }^{* * *}$, ${ }^{* *}$ and ${ }^{*}$ indicating significance at the $1 \%, 5 \%$ and $10 \%$ level, respectively.

\section{Unexpected Intervention}

By using the fitted values from the reaction function as instruments, the analysis up to this point has tested whether the systematic (i.e., expected) component of foreign exchange intervention could affect exchange rates. However, it is possible that the "surprise" element of intervention (rather than its expected component) has a significant effect on exchange rates.

To test this hypothesis, I try two alternative specifications. First, I decompose the actual amount of intervention into an expected component and unexpected one, the latter given by the residual term in the Tobit model used in the first stage. I then include both measures of intervention in the exchange rate equation (3) described in Section IV. The results in Table A. 3 show that, in line with the benchmark results, the effects of the predictable component of discretionary intervention is significant during the first period, but has no significant measurable impact during the second period. The unexpected amount of intervention, on the other hand, seems to have a consistently perverse effect in both periods: higher unexpected intervention actually led to a contemporaneous appreciation of the currency. 
Table A.3 The Impact of the Unexpected component of Central Bank Intervention

(Mean Returns Equation)

\begin{tabular}{|c|c|c|}
\hline & $\begin{array}{r}\text { First Period } \\
\text { September 2004-March } 2006\end{array}$ & $\begin{array}{r}\text { Second Period } \\
\text { January 2007-April } 2007\end{array}$ \\
\hline$\beta_{0}$ (Lagged Dependent Variable) (t-1) & $\begin{array}{l}0.251 * * * \\
(0.08)\end{array}$ & $\begin{array}{l}0.102 \\
(0.09)\end{array}$ \\
\hline \multicolumn{3}{|l|}{ Intervention Indicators } \\
\hline$\beta_{11}$ (Predicted Amount of Dollar Purchases by Central Bank) ( $\mathrm{t}$ ) & $\begin{array}{l}0.860 * * \\
(0.42)\end{array}$ & $\begin{array}{l}0.024 \\
(0.09)\end{array}$ \\
\hline$\beta_{12}$ (Unexpected Amount of Dollar Purchases by Central Bank) ( $t$ ) & $\begin{array}{l}-0.039 * * * \\
(0.01)\end{array}$ & $\begin{array}{l}-0.124 * * * \\
(0.04)\end{array}$ \\
\hline$\beta_{2}$ (Overnight Interest Rate Differential) (t) & $\begin{array}{l}-0.031 * * * \\
(0.01)\end{array}$ & $\begin{array}{l}-0.587^{* * *} \\
(0.17)\end{array}$ \\
\hline$\beta_{3}$ (Daily Change in EMBI Sovereign Spread) (t) & $\begin{array}{l}1.472 * * * \\
(0.21)\end{array}$ & $\begin{array}{l}1.835^{* *} \\
(0.84)\end{array}$ \\
\hline $\begin{array}{l}\text { Unexpected Component of Inflation Announcement } \\
\beta 4 \text { (Actual minus Expected Value of Inflation) (t-1) }\end{array}$ & $\begin{array}{l}0.432 * * \\
(0.21)\end{array}$ & $\begin{array}{l}-0.461^{* * *} \\
(0.10)\end{array}$ \\
\hline Dummy for Days with Automatic FX Intervention & Yes & Yes \\
\hline \multicolumn{3}{|c|}{ Diagnostics } \\
\hline $\begin{array}{l}\log L \\
\text { R-Squared } \\
\text { Included observations }\end{array}$ & $\begin{array}{r}-28.001 \\
0.157 \\
356\end{array}$ & $\begin{array}{r}-3.251016 \\
0.512 \\
73\end{array}$ \\
\hline
\end{tabular}

Source: Author's calculations.

Note: This table reports estimation of the Mean Equation of the $\operatorname{GARCH}(1,1)$ model in equation (3)-(5), augmented to account for the unexpected component of central bank intervention. The unexpected amount of intervention corresponds to the estimated residual values of the foreign exchange intervention policy reaction model fitted in the first stage. The coefficient on the intervention variable measures the pecentage change in the exchange rate for a US\$100 million in foreign currency purchases. Asterisks denote significance of coefficients, with ${ }^{* * *},{ }^{* *}$ and ${ }^{*}$ indicating significance at the $1 \%, 5 \%$ and $10 \%$ level, respectively.

An alternative way to measure the effect of unexpected intervention is to test whether central bank intervention was more effective on days when monetary authorities were perceived as least likely to have intervened. To implement this second specification, I first estimate a Probit model for the decision to intervene using a dummy variable that takes the value of 1 in days when the central bank intervened, and 0 otherwise. As explanatory variables, I use the same determinants as in the benchmark model. Using the fitted values of the discrete choice models as a measure of the ex-ante likelihood of central bank's presence in the market, I define days with a predicted probability below 0.5 as days with a low likelihood of intervention. ${ }^{66}$ I then include in the baseline model a multiplicative term capturing the interaction between the instrumented level of intervention and a dummy indicating days in which the BdR was less likely to have intervened. Results in Table A.4 indicate that the

\footnotetext{
${ }^{66}$ The median daily value of the predicted probability of intervention using the Probit model is 0.84 and 0.74 during the first and second period, respectively.
} 


\section{effects of BdR intervention were not significantly different in days with low perceived likelihood of central bank intervention.}

Table A.4 The Impact of Intervention in Days when the Central Bank was Less Likely to Have Intervened (Mean Returns Equation)

\begin{tabular}{|c|c|c|}
\hline & $\begin{array}{r}\text { First Period } \\
\text { September 2004-March } 2006 \\
\end{array}$ & $\begin{array}{r}\text { Second Period } \\
\text { January 2007-April } 2007 \\
\end{array}$ \\
\hline$\beta_{0}$ (Lagged Dependent Variable) (t-1) & $\begin{array}{l}0.261 * * * \\
(0.08)\end{array}$ & $\begin{array}{l}0.132 \\
(0.22)\end{array}$ \\
\hline \multicolumn{3}{|l|}{ Intervention Indicators: } \\
\hline$\beta_{11}$ (Predicted Amount CB Intervention) (t) & $\begin{array}{l}0.864 * * \\
(0.39)\end{array}$ & $\begin{array}{l}0.085 \\
(0.23)\end{array}$ \\
\hline$\beta_{12}$ (Dummy for Days in Which CB was Less Likely to Have Intervened) (t) & $\begin{array}{r}-0.116 \\
(0.16)\end{array}$ & $\begin{array}{l}0.083 \\
(0.25)\end{array}$ \\
\hline$\beta_{13}$ (Predicted Amount CB Intervention) X (Dummy for Less Likely CB Intervention) (t) & $\begin{array}{l}0.845 \\
(0.66)\end{array}$ & $\begin{array}{l}-0.187 \\
(0.42)\end{array}$ \\
\hline$\beta_{2}$ (Overnight Interest Rate Differential) (t) & $\begin{array}{r}-0.018 \\
(0.01)\end{array}$ & $\begin{array}{r}-0.377 \\
(0.25)\end{array}$ \\
\hline$\beta_{3}$ (Daily Change in EMBI Sovereign Spread) (t) & $\begin{array}{l}1.479 * * * \\
(0.25)\end{array}$ & $\begin{array}{l}2.114^{* *} \\
(0.91)\end{array}$ \\
\hline \multicolumn{3}{|l|}{ Unexpected Component of Inflation Announcement } \\
\hline B4 (Actual minus Expected Value of Inflation) (t-1) & $\begin{array}{l}0.469 * * \\
(0.19)\end{array}$ & $\begin{array}{l}-0.454 \text { *** } \\
(0.12)\end{array}$ \\
\hline Dummy for Days with Automatic FX Intervention & Yes & Yes \\
\hline \multicolumn{3}{|l|}{ Diagnostics } \\
\hline $\begin{array}{l}\log L \\
\text { R-Squared } \\
\text { Included observations }\end{array}$ & $\begin{array}{r}-108.442 \\
0.157 \\
356\end{array}$ & $\begin{array}{r}-5.81293 \\
0.436 \\
73\end{array}$ \\
\hline
\end{tabular}

Source: Author's calculations.

Note: This table reports estimation of the Mean Equation of the $\mathrm{GARCH}(1,1)$ model in equation (3)-(5), augmented to account for the interaction between the predicted amount of intervention and the ex-ante probability of central bank's presence in the foreign exchange market. The dummy variable takes the value of 1 in those days when the predicted probability of intervention was less than 0.5 . The coefficient on the intervention variable measures the pecentage change in the exchange rate for a US\$100 million in foreign currency purchases. Asterisks denote significance of coefficients, with ${ }^{* \star *}$, ${ }^{* *}$ and ${ }^{*}$ indicating significance at the $1 \%, 5 \%$ and $10 \%$ level, respectively. 


\section{REFERENCES}

Aizenman, J., and J. Lee, 2007. "International Reserves: Precautionary versus Mercantilist Views, Theory, and Evidence," Open Economy Review, Vol. 11, pp. 191-214.

Akici, O., Culha, O., Ozlale, U. and Sahinbeyoglu, G., 2005, "Causes and Effectiveness of the Foreign Exchange Interventions for the Turkish Economy," Research Department Working Paper No 05/05, Central Bank of the Republic of Turkey.

Almekinders, G. J., 1995, Foreign Exchange Intervention: Theory and Evidence (Aldershot, UK: Edward Elgar).

Baillie, R., and T. Bollerslev, 1989, "Common Stochastic Trends in a System of Exchange Rates" The Journal of Finance, Vol. 44, No. 1 (March), pp. 167-181.

Bank for International Settlements, 2005, "Foreign Exchange Market Intervention in Emerging Markets: Motives, Techniques and Implications," BIS Papers 24. Basel, Switzerland.

Bollerslev, T., and J. Wooldridge, 1992, "Quasi-Maximum Likelihood Estimation And Inference in Dynamic Models with Time-Varying Covariances," Econometric Reviews, Vol. 11(2), pp. 143-172.

Calvo, G. A., (1991), “The Perils of Sterilization,” Staff Papers, International Monetary Fund, Vol. 38 (4), pp 921-926.

— L. Leiderman, and C. M. Reinhart, (1993), "Capital Inflows and Real Exchange Rate Appreciation in Latin America: The Role of External Factors," Staff Papers, International Monetary Fund, Vol. 40 (1), pp 108-151.

Canales-Kriljenko, J., 2003, "Foreign Exchange Intervention in Developing and Transition Economies: Results of A Survey," IMF Working Paper 03/95 (Washington: International Monetary Fund).

Cashin, P., Edison, H.and Hong Liang, 2006, "Foreign Exchange Intervention and the Australian Dollar: Has It Mattered?" International Journal of Financial Economics, Vol. 11, No. 2, pp. 155-171.

Chang, R., 2007, "Inflation Targeting, Reserves Accumulation, and Exchange Rate Management in Latin America". Paper prepared for the FLAR Conference on International Reserves in Middle- and Low-Income Countries.

Clarida, R. and D. Waldman, 2007, "Is Bad News about Inflation Good News for the Exchange Rate?". Paper presented at the $8^{\text {th }}$ Jacques Polak Annual IMF Research Conference. 
Disyatat, P., and G. Galati, 2007, "The Effectiveness of Foreign Exchange Market: Intervention in Emerging Market Countries: Evidence from the Czech Koruna," Journal of International Money and Finance, Vol. 26(3), pp. 383-402.

Domac, I., and A. Mendoza, 2002, "Is There Room for Foreign Exchange Interventions Under an Inflation Targeting Framework? Evidence from Mexico and Turkey," Policy Research Paper No. 3288 (Washington: World Bank).

Dominguez, K. M., 1992, “The Informational Role of Official Foreign Exchange Intervention Operations: The Signalling Hypothesis," in Exchange Rate Efficiency and the Behavior of International Asset Markets, (New York: Garland Publishing Company), pp. 41-80.

— 1998, "Central Bank Intervention and Exchange Rate Volatility," Journal of International Money and Finance," Vol. 17, pp. 161-190.

—_, 2003, “The Market Microstructure of Central Bank Intervention,” Journal of International Economics, Vol. 59, pp. 25-45.

_ 2006, "When Do Central Bank Interventions Influence Intra-Daily and Longer-Term Exchange Rate Movements?” Journal of International Money and Finance, Vol. 25, pp. 1051-1071.

— (Washington: Institute for International Economics).

Edison, Hali J., 1993, “The Effectiveness of Central Bank Intervention: A Survey of the Literature After 1982," Special Papers in International Economics No 18. (New Jersey: International Finance Section, Princeton University).

- 1997, "The Reaction of Exchange Rates and Interest Rates to News Releases," International Journal of Finance and Economics, Vol. 2, pp. 87-100.

Edwards, S., 2006, “The Relationship between Exchange Rates and Inflation Targeting Revisited,” NBER Working Paper No. 12163 (Cambridge, Massachusetts: National Bureau of Economic Research).

Fatum, R., and M. Hutchison, 2003, "Is Sterilized Foreign Exchange Intervention Effective After All? An Event Study Approach,” The Economic Journal, Vol. 113, pp. 390411.

Gersl, A., and T. Holub, 2006, "Foreign Exchange Interventions under Inflation Targeting: The Czech Experience," Contemporary Economic Policy, 24 (4), pp. 475-491. 
Guimarães, R., and C. Karacadag, 2004, "The Empirics of Foreign Exchange Intervention in Emerging Market Countries: The Cases of Mexico and Turkey," IMF Working Paper 04/123 (Washington: International Monetary Fund).

Ho, C., and R. McCauley, 2003, "Living With Flexible Exchange Rates: Issues and Recent Experience in Inflation Targeting Emerging Market Economies," BIS Working Papers No. 130 (Basel: Bank for International Settlements).

Holub, T., 2004, "Foreign Exchange Interventions Under Inflation Targeting: The Czech Experience," Research and Policy Notes 2004/01 (Prague: Czech National Bank, Research Department).

Hutchinson, M., 2003, "Intervention and Exchange Rate Stabilization Policy in Developing Countries," International Finance, 6, pp. 109-127.

Imbens, G.W., 2004, "Nonparametric Estimation of Average Treatment Effects Under Exogeneity: A Review," Review of Economics and Statistics 86, 4-29.

International Monetary Fund, 2007a, Regional Economic Outlook, Asia and Pacific, October 2007: A Survey by the Staff of the International Monetary Fund, World Economic and Financial Surveys (Washington).

, 2007b, Regional Economic Outlook, Western Hemisphere, November 2007: A Survey by the Staff of the International Monetary Fund, World Economic and Financial Surveys (Washington).

, 2007c, World Economic Outlook, Fall (Washington).

Ito, T., 2002, "Is Foreign Exchange Intervention Effective? The Japanese Experience in the 1990s," NBER Working Paper No. 8914 (Cambridge, Massachusetts: National Bureau of Economic Research).

, and T. Yabu, 2006, "What Promotes Japan to Intervene in the Forex Market? A New Approach to a Reaction Function," forthcoming, Journal of International Money and Finance.

Jeanne, O. and R., Rancière, 2006, “The Optimal Level of International Reserves for Emerging Market Countries: Formulas and Applications," IMF Working Paper 06/229 (Washington: International Monetary Fund).

Kamil, H., and A. Reveiz, (2008) “Carry Trades, Special Vehicle Purposes and Derivatives Markets in Colombia: Mechanisms and Policy Implications," (unpublished; Washington: International Monetary Fund). 
Kearns, J., and R. Rigobon, 2005, "Identifying the Efficacy of Central Bank Interventions: Evidence from Australia and Japan," Journal of International Economics, 66, pp. $31-48$.

Krugman, Paul, 1979, “A Model of Balance-of-Payment Crises," Journal of Money, Credit, and Banking, Vol. 11(3), pp. 311-25.

Kumhof, M., Li, S. and I. Yan, 2007, "Balance-of-Payment Crises under Inflation Targeting," Journal of International Economics, Vol. 72(1), pp. 242-64.

Lall, S., 1997, "Speculative Attacks, Forward Market Intervention and the Classic Bear Squeeze," IMF Working Paper 97/164 (Washington: International Monetary Fund).

Lavigne, S., 2008, "Sterilized Intervention in Emerging-Market Economies: Trends, Costs, and Risks," Discussion Paper 2008-4 (Ottawa: Bank of Canada, Research Department).

Mandeng, O., 2003, "Central Bank Foreign Exchange Market Intervention and Option Contract Specification: The Case of Colombia," IMF Working Paper 03/135 (Washington: International Monetary Fund).

Mihaljek, Dubravko, 2005, "Survey of Central Banks' Views on Effects of Intervention," BIS Working Papers No. 24 (Basel: Bank for International Settlements).

Mohanty, M.S., and P. Turner, 2006, "Foreign Exchange Reserve Accumulation in Emerging Markets: What Are the Domestic Implications?" BIS Quarterly Review (September): $39-52$.

Moreno, R., 2005, “Motives for Intervention” BIS Papers No. 24b (Basel: Bank for International Settlements).

Naranjo, A. and M. Nimalendran, 2000, "Government Intervention and Adverse Selection Costs in Foreign Exchange Markets," The Review of Financial Studies, 13 (2), pp. 453-77.

Neely, C., 2000, "The practice of Central Bank intervention: Looking under the hood," Central Banking XI 2 , pp. 24-37

Neely, C. J., 2005, "An Analysis of Recent Studies of the Effect of Foreign Exchange Intervention," FRB of St. Louis Working Paper No.87 (St. Louis, Missouri: Federal Reserve Bank of St. Louis), pp. 685-718.

—_, 2008, "Central Bank Authorities' Beliefs About Foreign Exchange Intervention," Journal of International Money and Finance, 27(1), pp. 1-25. 
Ozge, A., Olcay Y. C., Ozlale, U., and G. Sahinbeyoglu, 2005, "Causes and Effectiveness of the Foreign Exchange Interventions for the Turkish Economy," Research Department Working Paper No 05/05, Central Bank of the Republic of Turkey.

Ramirez, J.M., 2004, "Foreign Exchange Market Intervention Through Options: the Case of Colombia," forthcoming in the proceedings of a conference held at the Czech National Bank in May 2004 on Practical Aspects of Inflation Targeting.

Reinhart, C., and V.R. Reinhart, 1998, "Some Lessons for Policy Makers Who Deal with the Mixed Blessing of Capital Inflows," in Capital Flows and Financial Crises, ed. by Miles Kahler (Ithaca, New York: Cornell University Press).

_ 2008, "Capital Flows and Reserve Accumulation: The Recent Evidence," NBER Working Paper No. 13842 (Cambridge, Massachusetts: National Bureau of Economic Research).

Sarno, L., and M. Taylor, 2001, "Official Intervention in the Foreign Exchange Market: Is It Effective and, If So, How Does It Work?" Journal of Economic Literature, Vol. 39(3), pp. 839-68.

Tapia, M., and A. Tokman, 2004, "Effects of Foreign Exchange Intervention Under Public Information: The Chilean Case," Economia, Spring 2004, Vol. 4 (2), pp. 215-256.

Toro, J., and J. M. Julio, 2006, "The Effectiveness of Discretionary Intervention by the Banco de la República on the Foreign Exchange Market," (unpublished; Bogotá: Banco de la República).

Uribe, J.D., 2005, "Capital Controls and Foreign Exchange Market Intervention in Colombia," in Globalisation and Monetary Policy in Emerging Markets, BIS Papers No. 24 (Basel: Bank for International Settlements).

— , and Jorge Toro, 2005, "Foreign Exchange Market Intervention in Colombia," in Foreign Exchange Market Intervention in Emerging Markets: Motives, Techniques and Implications, BIS Papers No. 24 (Basel: Bank for International Settlements)

Vargas, H., 2005, “Exchange Rate Policy and Inflation Targeting in Colombia," IDB Working Paper, No. 539 (Washington: Inter American Development Bank). 